\title{
WestVirginiaUniversity
}

THE RESEARCH REPOSITORY @ WVU

Graduate Theses, Dissertations, and Problem Reports

1999

\section{Perceptions of HIV/AIDS in West Virginia nursing facilities}

Valarie Ann Bell

West Virginia University

Follow this and additional works at: https://researchrepository.wvu.edu/etd

\section{Recommended Citation}

Bell, Valarie Ann, "Perceptions of HIV/AIDS in West Virginia nursing facilities" (1999). Graduate Theses, Dissertations, and Problem Reports. 1024.

https://researchrepository.wvu.edu/etd/1024

This Thesis is protected by copyright and/or related rights. It has been brought to you by the The Research Repository @ WVU with permission from the rights-holder(s). You are free to use this Thesis in any way that is permitted by the copyright and related rights legislation that applies to your use. For other uses you must obtain permission from the rights-holder(s) directly, unless additional rights are indicated by a Creative Commons license in the record and/ or on the work itself. This Thesis has been accepted for inclusion in WVU Graduate Theses, Dissertations, and Problem Reports collection by an authorized administrator of The Research Repository @ WVU. For more information, please contact researchrepository@mail.wvu.edu. 


\title{
PERCEPTIONS OF HIV/AIDS \\ IN \\ WEST VIRGINIA NURSING FACILITES
}

\author{
Valarie A. Bell
}

Thesis submitted to the School of Medicine

Department of Community Medicine at West Virginia University

in partial fulfillment of the requirements for the degree of

\author{
Master of Science \\ In \\ Community Health Promotion
}

Irene Tessaro, DrPH., Chair

R. Turner Goins, Ph.D

David K. Brown, Ph.D

Department of Community Medicine

Morgantown, West Virginia

1999

Keywords: HIV, AIDS, elderly, aging, nursing homes, Organizational Change Theory, West Virginia

Copyright 1999 Valarie A. Bell 


\section{ABSTRACT \\ Perceptions of HIV/AIDS in West Virginia Nursing Facilities}

\section{Valarie A. Bell}

Introduction: Placement of HIV/AIDS infected individuals into geriatric long-term care facilities has been a problem since the beginning of HIV/AIDS. Specific Aims: The objective of this study was to determine how prepared West Virginia nursing facilities are to deal with the HIV/AIDS population. Methods: An anonymous mailed survey guided by the organizational change theory was sent to all 144 certified nursing facilities within the state. Questions were asked about current policies, procedures, education, concerns, resources, and experiences specific to HIV/AIDS. Results: A total of 72 surveys were returned for a response rate of 50\%. Most facilities $(71.8 \%)$ offered educational programs about HIV/AIDS. Particular concerns about placement were: cost of care (57.7\%); and fear of infection (43.6\%). The majority of facilities (54.9\%) indicated they would accept HIV/AIDS infected persons, but only $7 \%$ of facilities were currently caring for one. There were few differences between study variables and size of nursing 


\section{TABLE OF CONTENTS}

List of Tables $\mathrm{V}$

\section{Chapter Title}

\section{Introduction}

A. Statement of Research Problem 1

B. Incidence and Prevalence of HIV/AIDS 1

C. West Virginia Profile 2

D. West Virginia HIV/AIDS Profile ___ 3

E. Increased Life Expectancy ___ 4

F. Younger Nursing Home Residents __ 5

G. Medicare/Medicaid __ 5

H. Staff Concerns

I. Community Resources ___ 8

J. Significance

K. Study Objectives

L. Research Questions __ 9

2. Background _ 10

A. Review of Literature

B. Theoretical Framework _ 15

3. Research Methods _ 18

A. Research Design __ 18

B. Study Variables __ 18

C. Study Population

D. Data Collection _ 20

E. Analysis _ 22

4. Results __ 23

A. Sample Characteristics __23

B. Response Rates __ 25

C. Descriptive Statistics by Region __ 28 
1. Policies and Procedures

2. Education _ 31

3. Concerns _ 33

4. Resources 34

5. Experiences _ 36

D. Bivariate Analysis __ 40

1. Policies and Procedures _ 40

2. Education 41

3. Concerns _ 43

4. Resources__ 43

4. Experiences _ 44

5. Discussion _ 46

A. Major Findings _ 46

1. Policies and Procedures _ 46

2. Education _ 47

3. Concerns — 47

4. Resources 48

5. Experiences _ 48

B. Organizational Stage by Nursing Facility __ 49

C. Study Limitations _ 51

D. Implications for Community Health Promotion

REFERENCES _ 55

APPENDICES _ 57

A. Copy of State Map \& Regions __ 57

B. $1^{\text {st }}$ Cover Letter

C. $2^{\text {nd }}$ Cover Letter

D. HIV/AIDS Survey _ 61

E. IRB Approval Notice__ 65 


\section{LIST OF TABLES}

Table 4.0 Total Number of Counties, Estimated Population, and Number of Metropolitan Areas for West Virginia by Region 23

Table 4.1 Response Rates from HIV/AIDS

Survey for All Regions in West Virginia 25

Table 4.2 Total Number of Certified Nursing Facilities and

Survey Responses in West Virginia by Size of Facility 26

Table 4.3 Total Number of Beds in each Certified Nursing Facility and each Participating Nursing Facility

In West Virginia by Region 27

Table 4.4 Polices \& Procedures about HIV/AIDS in West Virginia Nursing Facilities by Region 30

Table 4.5 Education about HIV/AIDS in West Virginia Nursing Facilities by Region 32

Table 4.6 Concerns about HIV/AIDS in

West Virginia Nursing Facilities by Region 34

Table 4.7 Resource Availability Specific to HIV/AIDS in West Virginia Nursing Facilities by Region 36

Table 4.8 Experiences Specific to HIV/AIDS in West Virginia Nursing Facilities by Region 39

Table 4.9 Policies \& Procedures Specific to HIV/AIDS in West Virginia Nursing Facilities by Size of Facility 41

Table 4.1.1 Education Specific to HIV/AIDS

In West Virginia Nursing Facilities by Size of Facility 42

Table 4.1.2 Concerns about HIV/AIDS in

West Virginia Nursing Facilities by Size of Facility 43

Table 4.1.3 Resource Availability Specific to HIV/AIDS in West Virginia Nursing Facilities by Size of Facility 44

Table 4.1.4 Experiences Specific to HIV/AIDS in

West Virginia Nursing Facilities by Size of Facility 45 


\section{CHAPTER 1: INTRODUCTION}

\section{Statement of Research Problem:}

Placement of HIV/AIDS infected individuals into primarily geriatric long-term care facilities has consistently been a problem since the beginning of HIV/AIDS. Low percentages of elderly persons' being diagnosed, little education and/or little recognition of the disease in rural areas, and the continued increase of infected individuals who are much younger than the typical nursing home resident, have lead some health care workers to believe that the nursing home industry may not have to deal with this disease. Other issues that have contributed to the reluctancy of nursing facilities to address HIV/AIDS is the cost of caring for infected individuals, which includes, monetary concerns, staffing concerns, and resource availability within the community. For these reasons, few nursing facilities originally designed for the geriatrics population, have been prepared to deal with HIV/AIDS (Fogarty et al., 1997).

\section{Incidence and Prevalence of HIV/AIDS:}

HIV/AIDS is less prevalent in individuals over the age of 50. Older adults have consistently populated only $10 \%$ of the AIDS population in the United States since the beginning of the disease, (Emlet, 1997) and only 9.2\% of West Virginia's population from 1984-1997 (Epidemiologic Profile of HIV/AIDS in West Virginia 1998). Due to the low percentage of older adults being diagnosed with this disease, the aging population has traditionally been classified as lower-risk. This perception could also be a result of the unwillingness of society to place this population into higher-risk behavior categories, such as, homosexual relationships, IV drug use, and/or multiple sex partners. Often, transmission of 
the disease in this population is attributed to blood transfusions. However, since 1985 donated blood has been screened for HIV/AIDS, making this theory somewhat unfounded (Emlet, 1997). The perception that "Grandma is too old to be HIV+ or to be at risk" has possibly lead to a favorable stereotype in some peoples opinion, but this stereotype may raise concerns for health care professionals who are working to prevent HIV/AIDS.

Infected individuals and higher-risk individuals have traditionally been classified as young homosexual males and/or IV drug users living in urban areas. This is primarily due to the diagnosis of HIV/AIDS originating in these populations, and the high incidence of disease occurring in urban areas of the country.

These misconceptions may seem very "outdated" to some researchers or clinicians that study this disease, but in rural areas where the prevalence of these high-risk populations, diagnosis, and disease is less than other areas of the country, the idea that "HIV/AIDS will never happen here" is still very present (MacDowell, 1989).

\section{West Virginia Profile:}

West Virginia's demographic statistics show that it has one of the largest elderly populations, lowest household incomes, and highest poverty levels in the US. The 1997 estimated population of the state is $1,811,156$. Approximately, $15.1 \%$ of West Virginia individuals are over the age of 65 . This statistic currently ranks West Virginia $4^{\text {th }}$ out of 50 states and the District of Columbia for having one of the largest elderly populations. It is projected that by the year 2025, the percentage of West Virginia's elderly will increase to 24.9\%, which will then rank West Virginia as $2^{\text {nd }}$ in the United States (US Bureau of Census). There are currently 144 certified nursing facilities within the state of West Virginia. These 
include both skilled and non-skilled facilities, as well as, skilled, acute care settings in located hospitals.

West Virginia also has the lowest household income of $\$ 25,354$ and the $5^{\text {th }}$ highest poverty level (19.9\%) in the United States (US Bureau of Census). All of these characteristics are evidence that West Virginia is a poor, rural state with a large population of lower-risk individuals.

\section{West Virginia HIV/AIDS Profile:}

The HIV/AIDS population continues to grow in West Virginia, as well as, in the United States. The increasing growth of this population, will likely result in increased demand for long-term care assistance. There are currently 4 facilities available within the state that specifically care for HIV/AIDS infected individuals (Personal Communications with local AIDS facility, July 1999).

West Virginia's HIV/AIDS statistics reflect that in 1984 only 6 cases of AIDS were reported in the state. In 1997 that statistic rose to 119 reported cases, which is 20 times higher than in 1984. The largest percent (46\%) of the total AIDS cases were reported among 30-39 years olds, but the 40-49 and 50+ age groups accounted for the increasing percentages of reported cases over the most recent three year period, 1995-1997 (Epidemiologic Profile of HIV/AIDS in West Virginia 1998). The growth of this population reinforces the reality that issues pertaining to HIV/AIDS will continue to be a concern for future years. 


\section{Increased Life Expectancy:}

West Virginia statistics show that $100 \%$ of all individuals diagnosed with AIDS between the years of 1984-1986 are deceased. This percentage begins a slow decline after 1986, and in 1997, only 13\% of individuals diagnosed with AIDS have died (Epidemiologic Profile of HIV/AIDS in West Virginia 1998).

Persons diagnosed with HIV/AIDS can now expect to live 10 to 15 years longer and experience a better quality of life then those individuals first diagnosed in the late 1980's. This is a considerable increase from the once low life expectancy of 3 to 6 months (Personal communications with local AIDS facility, July 1999). Due to this increase, those persons diagnosed in their 40's and 50's can now expect to live well into their 60's and 70's (Emlet, 1997), and are now considered to be "living with AIDS" (Personal communications with local AIDS facility, July 1999).

Increases in life expectancy of HIV/AIDS infected individuals have resulted in less people requiring immediate long-term care for treatment of HIV/AIDS infections, because of the increase in quality of life. Due to medical advancements infected individuals can now continue working, caring for their families, and participating in daily activities as they did prior to diagnosis (Personal communications with local AIDS facility). Those individuals who are seeking nursing home placement may now be seeking care due to the increased need to manage other illnesses, such as, cancer, and dementia and require less care to manage HIV/AIDS. For these reasons, HIV/AIDS is now being considered a co-factor or secondary diagnosis in a person's health status (Personal communications with local AIDS facility, July 1999). Local AIDS workers believe that although the crunch to place HIV/AIDS infected individuals into long-term care facilities has slowed down, those infected individuals will 
eventually require more extensive care and/or additional custodial care during the final stages of life. At this time, infected individuals who do not have a social support system or other means of available care will turn to skilled and/or non-skilled nursing home services (Personal communications with State AIDS program, July 1999).

\section{Younger Nursing Home Residents:}

Considering the largest population now being diagnosed with HIV/AIDS is the 30-39 age group, and the average age of nursing home residents is over the age of 79 (American HealthCare Association 1998) nursing homes need to be prepared to deal with not only the direct care of various illnesses associated with HIV/AIDS, but also the fact that patients may be younger than the average resident. A study by the University of Kentucky showed that many younger persons with AIDS (PWA's) are seeking nursing home placement as their disease progresses. This has been attributed to lack of family support, unavailability of family support due to elderly parents, geographic inaccessibility of children, siblings, or parents, and/or no family available (Linsk et al., 1993).

\section{$\underline{\text { Medicare/Medicaid: }}$}

With a majority of HIV/AIDS infected persons being diagnosed before the age of 65 , most infected individuals are too young to be eligible for Medicare and must rely on private insurance or Medicaid to pay for long-term care and/or in-home expenses. There are two requirements to be eligible for Medicare within the state of West Virginia. 1) disability for at least 2 years or 2) must be 65 years of age or older. Individuals must also meet pre-skilled care conditions, before Medicare will begin coverage. The conditions include, 1) patient 
requires skilled care or rehabilitation services that can only be provided in a skilled nursing unit, 2) patient must have been hospitalized 3 days in a row, not counting day of discharge, before entering facility, 3) patient must be admitted in facility no later than 30 days after leaving hospital, 4) patients condition for which their receiving care must be the same condition they were receiving care for in hospital or arose while receiving hospital treatment, and 5) a medical professional most certify need for daily skilled and/or rehabilitation care. If an individual does qualify for Medicare coverage, it will only pay for up to 100 days of skilled nursing care or rehabilitation services. . In the event that skilled care is not needed, Medicare pays nothing.

HIV/AIDS is now being viewed as a chronic disease rather than a terminal illness and is defined as a disability by the Americans with Disabilities Act of 1990. The 1990 ADA states that all communicable diseases, including HIV/AIDS are disabilities. (Fogarty et al., 1997). With the advances in treatment, extended life expectancy, and acceptance of the Americans with Disabilities Act for PWA's we can expect to see more individuals living long enough to qualify for Medicare, but again, if skilled nursing care is not required, Medicare pays nothing and all care expenses, either in-home or in long-term care facilities, will be the responsibility of the patient or Medicaid. The problem that arises with Medicaid residents is that although all state certified nursing facilities are mandated to have a percentage of Medicaid residents living within the facility, most nursing homes are reluctant to admit Medicaid individuals because of the low reimbursement rate. Medicaid pays for expenses based on an equerry level, which is the level of nursing care needed. Some individuals may require little nursing care, as defined by Medicaid, and require more custodial care, such as, changing of linens and clothing several times daily. Medicaid does not cover these activities. 
This, inturn, creates another problem with staff and availability of staff time to provide custodial care to high maintenance individuals. If nursing homes have a choice to admit a private pay individual or Medicaid individual, and their mandated Medicaid percentage has been reached, they can legitimately refuse the Medicaid individual (Personal Communications with State Medicaid Office, July 1999). Also, if they have a choice between those they typically serve, the elderly population, and PWA's they may choose the elderly individual due to their inability or unpreparedness to care for PWA's. These reasons may only double the difficulty in placement issues experienced by social workers and other professionals working with the HIV/AIDS population.

\section{$\underline{\text { Staff Concerns: }}$}

When addressing HIV/AIDS cost of care issues, nursing facilities must also address the cost associated with staffing issues, such as, staff inservice training specifically related to HIV/AIDS, recruitment and retention, and possible additions to staff due to increased demands of care from HIV/AIDS infected patients. Most nursing facilities that do not have policies and procedures in place to address issues dealing with HIV/AIDS and infected individuals, also do not have employees who are ready to deal with these issues. Local AIDS workers stated, "One of the biggest barriers facing the care of HIV/AIDS infected individuals is stigma (Personal Communication with Local AIDS Facility, July 1999)". Individuals who have little education in dealing with the disease usually carry homophobic anxieties, ignorance, or prejudices regarding PWAs (Fogarty et al., 1997). A study by Freeman (1988) states that effective educational programs and infection control procedures regarding HIV/AIDS are the "cornerstones" of good care in nursing homes. 


\section{Community Resources:}

Recognizing the resources available within the surrounding community, can help with the implementation of the facilities HIV/AIDS policies and procedures, as well as, help provide a comfortable environment for staff, other residents and family members by providing support, assistance, and education within the nursing home. Locating other agencies, such as, a local AIDS center, hospice organizations, bereavement counseling programs, and county health departments can be of an advantage to nursing homes who may have little or no experience in dealing with HIV/AIDS issues (Freeman, 1988).

\section{Significance:}

The significance of this study lies in the continuing increase in the incidence and prevalence of older adults and HIV/AIDS infected individuals in West Virginia. These populations have posed great challenges for the nursing home industries, which were already facing dilemmas concerning the aging population, such as, cost of care and availability. Although PWA's are living longer and accessing long-term care facilities less, they will inevitable require nursing assistance for complications related to aging and/or disease progression. With these ideas in mind all nursing facilities, regardless of demographics and geographic location, may find themselves face to face with providing care to HIV/AIDS infected persons.

\section{Study Objectives:}

The objective of this study was to determine how prepared West Virginia nursing facilities are to deal with HIV/AIDS. To gain a better understanding of how ready West 
Virginia is to accommodate this increasing population, data was collected from all West Virginia nursing homes regarding: current policies and procedures specific to admission and care of HIV/AIDS infected individuals; educational opportunities available within each facility about HIV/AIDS; concerns about placement of HIV/AIDS infected individuals; resources available within the community specific to HIV/AIDS; and experiences in dealing with HIV/AIDS.

$\underline{\text { Research Questions: }}$

The research questions used to guide this study are as follows:

1) At what stage of readiness are certified nursing homes in dealing with HIV/AIDS and infected individuals?
A) What are the policies and procedures concerning the admission and care of HIV/AIDS infected individuals?
B) What educational efforts about HIV/AIDS and infected individuals have been conducted?
C) What concerns do nursing facilities have about placement of HIV/AIDS infected individuals?
D) What resources are available outside of the nursing facility to assist with issues of HIV/AIDS?
E) What experiences have nursing facilities had in dealing with HIV/AIDS and infected patients?

2) What organizational factors are associated with each facilities current stage of readiness in certified nursing homes in West Virginia? 


\section{CHAPTER 2: BACKGROUND}

\section{$\underline{\text { Review of Literature: }}$}

HIV/AIDS infected persons face a variety of issues when considering nursing home placement. The issue of HIV/AIDS infection alone is enough of a concern without adding stigma, fear of transmission, cost of care, and availability of care.

The infected elderly face the same challenges, but often are the victims of other injustices, such as, misdiagnosis of HIV/AIDS and low levels of HIV/AIDS education. These mishaps are primarily due to the consistently low percentages of older adults being diagnosed with the disease, and they raise concerns for prevention and care of HIV/AIDS in the aging population. A study by Emlet discusses a study by Shuerman suggesting that misdiagnosis is one of the biggest problems facing the elderly infected with HIV/AIDS. Often symptoms mimic symptoms of other illness that affect the aging population, such as, dementia from AIDS infection being misdiagnosed as Alzheimer's Disease. Shuerman states “HIV/AIDS has also been misdiagnosed as respiratory disease, as well as, other non-AIDS-related diseases." He suggests that delays in diagnosis means delays in treatment, which could help promote a better quality of life, in addition to, a longer life expectancy for these individuals (Emlet, 1997).

Other concerns include the possibility that residents may be admitted into nursing facilities before being diagnosed with HIV/AIDS, and the fact that little education about the disease is being directed toward the elderly population. (Emlet, 1997). 
Elderly individuals who have little or no education about HIV/AIDS infections are more likely to be unaware of the symptoms and transmission of the disease, and are resistant to disclose their illness to friends and family members. Thus, making it difficult for many older PWA's to receive adequate care (outside of a nursing facility), which can accelerate the progression of their disease (Emlet, 1997).

Several studies addressing these issues, as well as, barriers associated with admission and care of HIV/AIDS infected individuals into long-term care facilities have been conducted since the beginning to the disease. Even though some of these studies are over ten years old, their data will reflect little change concerning the stigma of HIV/AIDS, and the continued concern for adequate care in this population.

An article written by Linsk, Cich and Cianfrani (1993) discussed four different surveys that addressed the issues of HIV/AIDS and long-term care. All studies were conducted in the late 1980's and produced very similar results.

The first study conducted in 1986 by the Minnesota AIDS Project used telephone interviews to address issues of HIV/AIDS care in 106 nursing homes within Minnesota. The results of this study showed that, 47 out of the 106 facilities surveyed, replied that they may provide services in the future to PWA's and 18 facilities reported that they would currently provide care, but when confronted with the placement of an HIV/AIDS infected individual only one facility agreed to admission (Linsk et.al, 1993).

The second study conducted in 1986 surveyed 240 Illinois nursing homes and reported that out of 35 respondents, 7 planned to admit a patient with AIDS, 24 did not, and 4 were uncertain (Linsk et.al, 1993). 
The third study conducted by Carner and Bressler (1987) surveyed 204 Pennsylvania nursing homes and addressed the issue of lack of accessibility to care for PWA's. A total of 54 administrators responded to the survey. Results showed that $40 \%$ said that they would not be willing to accept any AIDS patients, $49 \%$ were unsure, $6 \%$ indicated that they would accept at least one PWA, and 5\% indicated that they would only provide care to a PWA if that individual was currently a resident. Reasons for rejecting PWA's included, “presently no isolation areas in facility, concern for both staff and patient safety, lack of staff education, inappropriate reimbursement, fear of losing future admissions, and union problems with staffing" (Linsk et.al, 1993).

The fourth study conducted in 1988 by the Wisconsin Department of Health and Social Services surveyed all licensed nursing homes in the state on admission policies of HIV/AIDS infected individuals. The results showed that out of 277 responding homes only 36 were approached to admit a person with HIV infection. It also stated that out of those 36 facilities, only two reported that they had knowingly admitted a PWA. The other 241 facilities, that had not received any requests to admit PWA's, indicated that $20 \%$ would admit someone with HIV or AIDS, $69 \%$ indicated they would not, and 10\% were undecided (Linsk et al., 1993).

In 1988 a survey was conducted targeting 900 administrators of all long-term care facilities certified by the State of Ohio. A mail-in questionnaire was used. It consisted of 25 questions which included questions about facility and staff characteristics, care of AIDS infected patients, admission policies about AIDS infected patients, concerns about admission of AIDS infected patients, and suggested alternatives for care of AIDS infected patients. Several study variables were identified including, size of facility and geographical location. 
The results stated that only $10 \%$ of all nursing homes surveyed agreed to consider admission of AIDS infected patients. Variables addressing facility size, location, or being in a multiinstitutional system did not have an affect on consideration to admit an HIV/AIDS infected person ( MacDowell, 1989).

In 1993 another study conducted by Cich and Linsk reported that $45 \%$ of Chicago area nursing homes admitted to refusing placement of AIDS infected patients. In fact, the researchers found the situation so bad that social workers didn't even bother to try to place infected patients in local facilities. When asked about why their facilities rejected patients they stated that the admittance of AIDS infected residents "would lower staff recruitment, decrease referrals, cause conflict among residents, and cost more than average care" (Linsk et al., 1993).

Most of these studies were done early on and do not reflect current laws pertaining to HIV/AIDS infected individuals or the increase of knowledge about the disease related to transmission, detection, and diagnosis. These articles show how stigma has affected the care of the HIV/AIDS population, and are evidence that, at the beginning of the disease, few nursing facilities were willing to address issues of HIV/AIDS and infected individuals.

A 1992 article from the American Geriatric Society stated that only 7 out of all 51 states and the District of Columbia had defined those communicable diseases that would be allowed in their facilities. Out of these 7 only 3 specifically stated blood-borne pathogens or AIDS. In fact, in most states the only admission policy for communicable diseases were " those that could be cared for would be admitted." When asked directly about information concerning admission of AIDS infected individuals most facilities replied, "the state required universal precautions in all of their institutions and that federal law does not allow discrimination 
against patients with HIV infection." In addition to the 7 states that were reported to specify blood-borne pathogens or AIDS in their admission policies the article did report that eight states, including West Virginia, did correspond with information that their state received about AIDS infection. The article did not say if this information pertained to admission of HIV/AIDS infected individuals or was simply educational material used at the facility (Crossley et al., 1992).

The current West Virginia rules and regulations as stated in the West Virginia Division of Health Legislative Rules Title 64, Series 13 states that "To ensure its responsibility for the care provided to its residents, a facility shall admit only those persons whose needs it can meet with its services alone or in cooperation with other providers with whom it has appropriate written agreements." The West Virginia rule reflects the results of the prior study, which looked at specific admission requirements of special needs residents. The West Virginia Nursing Home Licensure rules give no further information about admission policies pertaining to individuals with specific care needs (West Virginia Division of Health Legislative Rules Title 64, Series 13, Nursing Home Licensure Rule 1997). The policy of "those who could be cared for" is very broad and many reasons for non-acceptance of an individual can be placed under this rule, such as, cost of continuing education and turnover rates, neither of which concern the direct care of the infected individual.

In 1998 an article by Heath discussed a long-term care facilities experiences in trying to develop an admission program for patients with AIDS who required skilled nursing care. The facility is located in central New York and serves as a training site for second and third year medical residents. The facility embarked on this 26-month experiment as a response to a funding initiative from the New York State Department of Health. The objective was to 
increase nursing home participation in HIV/AIDS care. The first 18-months were considered a preparation period. During this time, six mandatory in-service training sessions were completed for clinical and non-clinical staff. All attendants were given the opportunity to discuss varies issues of HIV/AIDS. After the initial preparation period patients with AIDS began to be admitted. During the 26-month period there were a total of 42 admissions by 32

patients. Twenty-nine admissions died while inside the facility, 13 were discharged, and 6 of the 13 discharged into the community care setting were rehospitalized and returned to the nursing home. During evaluation of the program, issues that developed as problems were balancing nutritional needs and time intensive feeding assistance of HIV/AIDS infected patients with other patients care needs, and the need to decide and agree on reasonable goals of therapy for each HIV/AIDS infected patient. An issue that was of an advantage was the educational sessions about HIV/AIDS prior to the admission of an HIV/AIDS infected patients (Heath, 1998).

The proposed study will look at current polices, procedure, knowledge, concerns, resources and experiences in West Virginia nursing homes concerning HIV/AIDS and determine on how prepared West Virginia nursing facilities are is to deal with the HIV/AIDS population, as well as, issues related to HIV/AIDS.

\section{Theoretical Framework:}

A stage theory of organization change was used to guide this study and assisted in how ready West Virginia nursing homes were to deal with the HIV/AIDS population. Organizational theory can be described as a stepladder. Each step is a different part of the organization and each step most be reached in order to get to the top. The stage theory of 
organizational change explains how organizations develop and implement new ideas, programs, policies, etc. As organizations begin to develop new policies they go through a cycle of stages. Beyer and Trice (1978) developed the organizational stage theory most commonly used. This model consists of seven stages:

1) Sensing of unsatisfied demands on the system

2) Search for possible responses

3) Evaluation of alternatives

4) Decision to adopt a course of action

5) Initiation of action within the system

6) Implementation of the change

7) Institutionalization of the change

Each of these stages describes how organizations gradually move from one step to the next until a policy is implemented and institutionalized. In this study implementation of a new policy or program is not an issue, therefore only the first 4 stages of the theory will be used. This study will use the overall percentage totals for each specific survey question to show where facilities stand in relation to each stage of the theory.

The definitions used for each stage in regards to this study are:

1) Sensing of unsatisfied demands on the system: Nursing facility has concerns about placement of HIV/AIDS infected individuals; incidents have occurred within facility relating to HIV/AIDS; at times staff has made it difficult to admit HIV/AIDS infected patients. 
2) Search for possible responses: Addresses the issues of what is currently being done within nursing facility to prepare for HIV/AIDS population; nursing facility has minimal/no policies and procedures specific to HIV/AIDS established; minimal/no educational efforts within facility; minimal/no resources available within community to assist facility in caring for HIV/AIDS infected individuals.

3) Evaluation of alternatives: Resources are available within the community to assist nursing facility in caring of HIV/AIDS infected patient; nursing home would consider admission of HIV/AIDS infected individual.

4) Decision to adopt a course of action: There are currently policies and procedures about admission and care of HIV/AIDS infected individuals; there are educational program available specific to HIV/AIDS issues; facility may or may not currently be caring for an infected person. 


\section{CHAPTER 3: RESEARCH METHODS}

\section{$\underline{\text { Research Design: }}$}

The proposed research uses a cross-sectional research design to gain an understanding of the readiness to change regarding the admission and care of HIV/AIDS infected individuals into long-term care facilities in West Virginia.

\section{Study Variables:}

The main study variables that are operationalized are readiness to change, policies, procedures, education, concerns, resources, and experiences.

1) Organizational readiness to change: survey questions addressing how prepared each facility is to care for HIV/AIDS infected individuals. These questions include what current policies and procedures do each nursing facilities have regarding the admission and care of HIV/AIDS infected individuals, does nursing facility offer educational programs specific to HIV/AIDS, what concerns do nursing homes have about the placement of an HIV/AIDS infected person, what resources are available within the community to assist each nursing facility with HIV/AIDS issues, and what type of experience do nursing facilities have addressing HIV/AIDS issues.

2) Organizational policies concerning HIV/AIDS and infected individuals: survey question addressing the current polices regarding admission and care of HIV/AIDS infected individuals. These questions address if nursing facilities have specific policies regarding admission and care of HIV/AIDS infected individual, policies regarding communicable disease, a policy stating those persons giving direct care to HIV/AIDS infected individuals are 
to be informed of their illness, and policies regarding who is to be informed of the infected individuals illness once admitted in the nursing facility.

3) Organizational procedures concerning HIV/AIDS infected individual: survey questions addressing the current procedures regarding admission and care of HIV/AIDS infected individuals. These questions address if nursing facilities have specific procedures involved in the admission and care of HIV/AIDS infected individuals, procedures regarding admission and care of special needs residents, other then HIV/AIDS infected persons, and if universal precautions are a considered substitute for a specific procedure.

4) Organizational education efforts toward HIV/AIDS and infected individuals: survey questions asking about current or requested educational efforts of each facility addressing issues specific to toward HIV/AIDS. These questions address the types of educational programs offered at each nursing facility, the amount in which each are offered, and the content of each session specifically relating to HIV/AIDS issues.

5) Organizational concerns about HIV/AIDS infected individuals: a survey question addressing the concerns about placement of an HIV/AIDS infected person. This question addresses the concerns that nursing facilities may have about admission and/or care of HIV/AIDS infected individuals.

6) Community resources, specific to HIV/AIDS, available to nursing facilities: survey questions addressing the availability of resources within the community to assist each facility in caring for HIV/AIDS infected individuals. These questions address the availability of outside resources to help nursing facilities address issues of HIV/AIDS, and assess if nursing facility is currently able to meet the medical and custodial care needs of HIV/AIDS infected residents. 
7) Organizational experiences related to HIV/AIDS: survey questions addressing each facilities experience in dealing with HIV/AIDS. These questions address the current experience that each facility has in caring for an HIV/AIDS infected person, if facility has ever been asked to care of an HIV/AIDS infected person and could not, would facility consider admission of HIV/AIDS infected person, have any incidents occurred within the facility relating to the subject of HIV/AIDS, and have any staff member ever threatened to quit if they had to care for infected individuals.

$\underline{\text { Study Population: }}$

All 144 certified nursing facilities within the State of West Virginia were eligible to be surveyed. A copy of all certified facilities obtained from the West Virginia State Licensure Board of Nursing Facilities was used to guarantee that all facilities within the state were reached.

\section{Data Collection:}

The sampling frame for this study was all certified nursing facilities within the state of West Virginia. A mailed questionnaire was used due to the scattered distribution of these nursing homes and low budget availability. An anonymous questionnaire was sent to all Social Services Directors working in all certified nursing facilities within the state. This questionnaire consisted of 30 questions addressing: policies, procedures, education, concerns resources, and experiences regarding HIV/AIDS. An anonymous questionnaire was chosen to encourage a higher response rate. The Social Services Director was identified as the key informant at each facility. A cover letter explaining the study was sent along with the 
questionnaire to encourage facilities to respond. A cover letter containing three signatures of support from state agency representatives that are affiliated with health care in the elderly, and HIV/AIDS prevention was sent along with the second distribution of the survey to help reinforce the legitimacy of the study and to encourage facilities to respond. All participants were reminded, in both the cover letters, that the survey was an organizational survey and all answers should be from the viewpoint of the entire nursing home. Completion of the survey was encouraged to be a group effort, possibly including the Administrator, Director of Nursing, and Inservice Coordinator. (See Appendix B and C for copies of letters)

One week after the initial distribution of the survey a reminder postcard was sent to all certified facilities, asking participants to respond. The postcard explained again that the survey was anonymous and to disregard the card if they had already completed and returned the questionnaire. Two weeks after the initial distribution, a second survey and cover letter were sent to all certified facilities asking, again, for participants to respond. Again, the cover letter explained that the survey was anonymous and to disregard if they had already completed and returned the questionnaire. The letter also reminded facilities of the organizations that were supporting the study, and encouraged them to contact the project coordinator or the supporting organizations for questions or verification of information.

After the initial distribution the facilities were given four weeks to respond to the survey. During the fourth week all nursing facilities were sent a thank you card for participating in the study. The card encouraged those who did not respond, to respond immediately or to contact the project coordinator for an additional copy of the survey if they had misplaced their copies. It also thanked those individuals who did participant and explained that a follow-up report would be sent to them after completion of the study. 
Analysis:

The statistical program JMP was used to analysis the response data. Descriptive statistics were calculated by region of location to present an overall representation of the data. Bivariate analysis assessed organizational factors of policy and procedures, continuing education, concerns of staff about HIV/AIDS, resources available within the community specific to HIV/AIDS, and experiences with HIV/AIDS by size of nursing facility. The size of the nursing facilities were defined as larger facilities: those facilities with more than 90 beds, and smaller facilities: those facilities with 90 or fewer beds. 


\section{CHAPTER 4: RESULTS}

\section{$\underline{\text { Sample Characteristics }}$}

TABLE 4.0. TOTAL NUMBER OF COUNTIES, ESTIMATED POPULATION, AND NUMBER OF METROPOLITAN AREAS FOR WEST VIRGINIA BY REGION

\begin{tabular}{|c|c|c|c|}
\hline Region & $\begin{array}{l}\text { Total \# of } \\
\text { counties }\end{array}$ & 1998 Estimated population * & $\begin{array}{c}\text { \# of metropolitan areas, } \\
\text { 1997** }\end{array}$ \\
\hline Region I & 16 & 509,348 & 3 \\
\hline Region II & 11 & 579,904 & 2 \\
\hline Region III & 15 & 341,276 & 0 \\
\hline Region IV & 13 & 380,628 & 0 \\
\hline
\end{tabular}

*Source: US Census Bureau website: http://www.census.gov/population/www/estimates/countypop.html ** Source: US Census Bureau website: www.census.gov/Press-Release/metro01.prn

Table 4.0 shows the number of counties, estimated populations and number of metropolitan areas per region. Characteristics of all regions were reviewed to help explain data results (See Appendix A for copy of state map with designated regions).

The metropolitan areas of West Virginia were defined as, metropolitan statistical areas or MSA's, with the exception of Charleston, West Virginia. The 1996 US Census Bureau statistics showed $41.8 \%$ of West Virginians living in Metropolitan areas. This average is low when compared to the United States statistic of 79.8\% (US Census Bureau website: www.census.gov/statab/www/states/wv.txt). Region I and Region III, are areas in West Virginia that contain the most counties. Region I is the most northern region of the state and consists of 16 counties, including Hancock, Monongalia, Calhoun, and Wood. It has the highest number of total nursing facilities (45) and the second highest population estimate $(509,348)$ for 1997 . Much of this population may be attributed to the region containing 3 metropolitan areas and West Virginia University, which is the largest university in the state. 
The metropolitan areas include Parkersburg, located in Wood County, Wheeling, located in Ohio County, and Weirton, located in Brooke County. Portions of these areas also extend into the state of Ohio.

Region II is located in the southwestern part of the state. Is the smallest region in the state, consisting of only 11 counties, including Jackson, Kanawha, Mingo, and Cabell. It has the second highest number of total nursing facilities (35), and the largest estimated population $(579,904)$ in the state. Much of this regions population may be attributed to this region containing 2 metropolitan areas, including Charleston, the single largest city in West Virginia, located in Kanawha County, and Huntington, located in Cabell County. A portion of Huntington's metropolitan area extends in the state of Kentucky. It also includes Marshall University, the second largest university in the state. Charleston's estimated population alone is over 200,000. It is the state capital of West Virginia and is the home of most of the state and federal programs.

Region III is located east of Region I and consists of 15 counties, including Preston, Jefferson, Randolph, and Lewis. Although, it contains the second highest number of counties it has the smallest estimated population $(341,276)$ for all regions. There are no metropolitan areas in this region.

Region IV, which is located in the southeastern part of the state, consists of 13 counties, including Braxton, Pocahontas, McDowell, and Fayette. This region has the second smallest number of counties and estimated population $(380,628)$. There are no metropolitan areas located in this region. 


\section{$\underline{\text { Response Rates }}$}

All 144 certified nursing facilities within the state of West Virginia were surveyed. A total of 72 surveys were returned for a response rate of $50 \%$. Each facility was categorized by region of location and number of beds in facility for the purpose of data analysis. A total of 71 ( $49.3 \%)$ response surveys were used when analyzing the facilities by region, and $70(48.6 \%)$ response surveys were used when comparing facilities by number of beds. One facility did not designate their region of location, and two did not designate their total number of beds.

The response rate of any study, especially an anonymous mail-in survey is vital to researchers when trying to prevent response bias. A response rate that represents the total sample population and a high percentage of responses are both desired. A response rate of $50 \%$ is considered adequate for data analysis and reporting (Babbie, 1989). The following tables represent the response rates from this survey, by region and size of facility.

Table 4.1 shows the total number of facilities and response rates by region. As can be seen, all regions are fairly equally represented, with Region IV having a somewhat smaller response rate than the other regions.

\section{TABLE 4.1. PERCENTAGES \& FREQUENCIES OF RESPONSE RATES FROM HIV/AIDS SURVEY} FOR ALL REGIONS IN WEST VIRGINIA

\begin{tabular}{|l|c|c|c|}
\hline Region & Total \# of facilities & \multicolumn{2}{c|}{ Total \# and \% of responses } \\
\hline & & N* & $\%$ \\
\hline Region I & 43 & 24 & 55.8 \\
\hline Region II & 35 & 17 & 48.5 \\
\hline Region III & 33 & 17 & 51.5 \\
\hline Region IV & 33 & 13 & 39.3 \\
\hline Total & 144 & 71 & 49.3 \\
\hline
\end{tabular}


Table 4.2 shows the response rate for those facilities with $\leq 90$ and those with $>90$ beds. Among the 144 facilities in the state, $59 \%$ have $\leq 90$ and $40.9 \%$ have $>90$. The response rate for each size was very similar. The larger facilities accounted for $42.8 \%$ of the survey responses, and the smaller facilities represented $57.0 \%$.

TABLE 4.2. PERCENTAGES \& FREQUENCIES FOR THE TOTAL NUMBER OF CERTIFIED NURSING FACILITIES AND SURVEY RESPONSES IN WEST VIRGINIA BY SIZE OF FACILITY

\begin{tabular}{|l|c|c|c|c|}
\hline & Total \# of beds $\mathbf{5 9 0}$ & \multicolumn{3}{|c|}{ Total \# of beds $>\mathbf{9 0}$} \\
\hline $\begin{array}{l}\text { Total number of facilities surveyed: } 144 \\
\text { ** }\end{array}$ & $\mathbf{N *}$ & $\mathbf{\%}$ & $\mathbf{N}$ & 40.9 \\
\hline Total number of survey responses: 70 & 85 & 59.0 & 59 & \\
\hline
\end{tabular}

* Number of facilities

** Source: List of all certified nursing facilities from the West Virginia State Board of Licensure and Certification.

Table 4.3 shows the total number of beds $\leq 90$ and $>90$ within each region and the total number of beds by survey response that are $\leq 90$ and $>90$ within each region. Region I has a fairly equal representation of smaller and larger facilities. Region II had a lower response rate for $\leq 90$ bed size. This may be due to fewer nursing homes in that region having less than 90 beds. Region III and Region IV had a higher response rate from smaller facilities. These responses may be due to a greater percentage of nursing facilities within those regions having less than 90 beds. 
TABLE 4.3. PERCENTAGES \& FREQUENCIES FOR THE TOTAL NUMBER OF BEDS IN EACH CERTIFIED NURSING FACILITY AND EACH PARTICIPATING NURSING FACILITY IN WEST VIRGINIA BY REGION

\begin{tabular}{|c|c|c|c|c|c|c|}
\hline \multirow[t]{2}{*}{ Region } & \multirow[t]{2}{*}{$\begin{array}{l}\text { Total \# of } \\
\text { facilities }\end{array}$} & \multicolumn{2}{|c|}{$\begin{array}{l}\text { Total \# of facilities } \\
\quad \leq 90 \text { beds }\end{array}$} & \multirow[t]{2}{*}{$\begin{array}{l}\text { Total \# of } \\
\text { survey } \\
\text { responses }\end{array}$} & \multicolumn{2}{|c|}{$\begin{array}{l}\text { Total \# of facilities } \\
\leq \quad 90 \text { beds }\end{array}$} \\
\hline & & $\mathbf{N}$ & $\%$ & & $\mathbf{N}^{*}$ & $\%$ \\
\hline Region I & 43 & 25 & 58.1 & 23 & 12 & 54.1 \\
\hline Region II & 35 & 16 & 45.7 & 17 & 5 & 29.4 \\
\hline Region III & 33 & 21 & 63.6 & 17 & 12 & 70.5 \\
\hline Region IV & 33 & 23 & 69.9 & 13 & 11 & 84.6 \\
\hline Total & 144 & 85 & 59.0 & 70 & 40 & 57.1 \\
\hline
\end{tabular}




\section{Descriptive Statistics by Region}

\section{$\underline{\text { Policies and Procedures }}$}

Table 4.4 shows the policies and procedures of West Virginia nursing facilities specific to HIV/AIDS issues by region of location. All numbers and percentages shown are the total number of facilities that currently have a written policy and/or procedure specific to HIV/AIDS, and/or offered HIV/AIDS testing to staff and residents. A total of $21.1 \%$ of all facilities that responded had a specific policy and procedure about the admission of HIV/AIDS infected individuals. With the exception of question 8 and 9, Region I consistently had a higher percentage of positive responses in all questions.

A total of $98.5 \%$ of all facilities indicated that they do have a communicable disease policy, while only $60.5 \%$ reported the policy included HIV/AIDS infected individuals. Some facilities commented that a specific admission policy was considered to be part of the communicable disease policy to prevent discrimination. Most facilities (69\%) considered Universal Precautions a substitute for a specific written procedure.

Few facilities $(11.2 \%)$ reported that a specific written policy was available stating that individuals who provide direct care to HIV/AIDS infected person(s) within the facility are to be informed of the patient's illness. Some facilities explained that they have no formal notification policy, but the information would be part of the residents chart/medical records, so individuals with access to those records would have access to the information, although, attempts would be made to maintain confidentiality. Others explained that it was at the discretion of the infected resident as to who was informed of the illness, or individuals would be informed only on a "need to know" basis. Participating facilities reported most frequently that the Medical Director of facility (80.2\%), the Director of Nursing, (78.8\%), the Social 
Services Director (74.6\%), RN's and LPN's (54.9\%), and certified nursing assistants (25.3\%) would be informed about the status of an HIV infected resident. Many facilities commented that the Administrator, Social Services Director, Medical Director, and Director of Nursing are all aware of medical diagnosis of all new residents, but the charge nurse and/or Infection control nurse would be the only nursing staff, including nursing assistants, to be informed unless exposure occurs.

Most facilities offered AIDS testing to staff and residents, but specified that it was usually only after a needle-stick, exposure, or if requested by the medical director or resident. 
TABLE 4.4. PERCENTAGES \& FREQUENCIES OF "YES" RESPONSES TO FOLLOWING QUESTIONS REGARDING POLICIES \& PROCEDURES SPECIFIC TO HIV/AIDS IN WEST VIRGINIA NURSING FACILITIES BY REGION

\begin{tabular}{|c|c|c|c|c|c|c|c|c|c|c|}
\hline \multirow[t]{2}{*}{ Question } & \multicolumn{2}{|c|}{ Region I } & \multicolumn{2}{|c|}{ Region II } & \multicolumn{2}{|c|}{ Region III } & \multicolumn{2}{|c|}{ Region IV } & \multicolumn{2}{|c|}{ Total } \\
\hline & $\mathbf{N}^{*}$ & $\%$ & $\mathbf{N}$ & $\%$ & $\mathbf{N}$ & $\%$ & $\mathbf{N}$ & $\%$ & $\mathbf{N}$ & $\%$ \\
\hline $\begin{array}{l}\text { Written policy for } \\
\text { admission of } \\
\text { HIV/AIDS pt. ** }\end{array}$ & 8 & 33.3 & 2 & 11.7 & 3 & 17.6 & 2 & 15.3 & 15 & 21.1 \\
\hline $\begin{array}{l}\text { Written procedures } \\
\text { for admission of } \\
\text { HIV/AIDS pt. }\end{array}$ & 9 & 37.5 & 2 & 11.7 & 2 & 11.7 & 2 & 15.3 & 15 & 21.1 \\
\hline $\begin{array}{l}\text { Written policy for } \\
\text { care of HIV/AIDS pt. }\end{array}$ & 10 & 41.6 & 2 & 11.7 & 5 & 29.4 & 3 & 23.0 & 20 & 28.1 \\
\hline $\begin{array}{l}\text { Written procedure } \\
\text { for care of } \\
\text { HIV/AIDS pt. }\end{array}$ & 9 & 37.5 & 4 & 23.5 & 5 & 29.4 & 3 & 23.0 & 21 & 29.5 \\
\hline $\begin{array}{l}\text { Written policy on } \\
\text { communicable } \\
\text { disease }\end{array}$ & 24 & 100 & 17 & 100 & 16 & 94.1 & 13 & 100 & 70 & 98.5 \\
\hline $\begin{array}{l}\text { Written procedure on } \\
\text { special needs pt. }\end{array}$ & 18 & 75.0 & 7 & 41.1 & 12 & 70.5 & 6 & 46.1 & 43 & 60.5 \\
\hline $\begin{array}{l}\text { Written policy for } \\
\text { persons providing } \\
\text { direct care }\end{array}$ & 3 & 12.5 & 2 & 11.7 & 2 & 11.7 & 1 & 7.6 & 8 & 11.2 \\
\hline $\begin{array}{l}\text { Does NH offer AIDS } \\
\text { testing to staff? }\end{array}$ & 16 & 66.6 & 8 & 47.0 & 12 & 70.5 & 9 & 69.2 & 45 & 63.3 \\
\hline $\begin{array}{l}\text { Does NH offer AIDS } \\
\text { testing to pt.? }\end{array}$ & 15 & 62.5 & 11 & 64.7 & 13 & 76.4 & 7 & 53.8 & 46 & 64.7 \\
\hline
\end{tabular}

* Number of responses

** pt.: patient 


\section{Education}

Table 4.5 shows the type and content of educational programs within each region. All numbers and percentages shown are the total number of facilities that currently provide educational programs specific to HIV/AIDS issues. Most participating facilities offered educational programs about HIV/AIDS (71.8\%). A total of $60.5 \%$ of these programs were offered annually, and $23.9 \%$ were offered on request. Less than $5 \%$ were offered quarterly or monthly. Although a majority of all participants indicated that their facility offered education about HIV/AIDS, less than half of them indicated they did education about sexuality/same sex issues (30.9\%) and drug use and abuse (39.4\%). The educational content of the HIV/AIDS programs included transmission of the disease and risk factors.

Most facilities indicated that all nursing home staff was required to attend a certain percentage of inservice programs $(94.3 \%)$. Some explained that attendance was mandatory for all staff, others commented the nursing staff must maintain a $90 \%$ attendance rate annually, and others explained they had a mandatory attendance of $75 \%$ to $95 \%$ annually for all employees. A total of $87.3 \%$ of participating facilities within the state indicated that there is staff available within their facility to educate others about HIV/AIDS. They did not indicate if the staff members were part of the nursing/medical department, infection control, or social services. Region III appears to have more education occurring on all topics. Region I has less than the sample average (57.7\%) of educational programs about HIV/AIDS. 
TABLE 4.5. PERCENTAGES \& FREQUENCIES OF “YES” RESPONSES TO FOLLWING QUESTIONS REGARDING EDUCATION SPECIFIC TO HIV/AIDS IN WEST VIRGINIA NURSING FACILITIES BY REGION

\begin{tabular}{|c|c|c|c|c|c|c|c|c|c|c|}
\hline \multirow[t]{2}{*}{ Questions } & \multicolumn{2}{|c|}{ Region I } & \multicolumn{2}{|c|}{ Region II } & \multicolumn{2}{|c|}{ Region III } & \multicolumn{2}{|c|}{ Region IV } & \multicolumn{2}{|c|}{ Total } \\
\hline & $\mathbf{N}^{*}$ & $\%$ & $\mathbf{N}$ & $\%$ & $\mathbf{N}$ & $\%$ & $\mathbf{N}$ & $\%$ & $\mathbf{N}$ & $\%$ \\
\hline \multicolumn{11}{|c|}{ Does facility offer educational programs about: } \\
\hline HIV/AIDS & 16 & 66.6 & 12 & 70.5 & 14 & 82.3 & 9 & 69.2 & 51 & 71.8 \\
\hline Sexuality & 11 & 45.8 & 2 & 11.7 & 6 & 35.2 & 3 & 23.0 & 22 & 30.9 \\
\hline Drug use $\&$ abuse & 10 & 41.6 & 6 & 35.2 & 8 & 47.0 & 4 & 30.7 & 28 & 39.4 \\
\hline \multicolumn{11}{|c|}{ Do educational programs include information about: } \\
\hline $\begin{array}{l}\text { Transmission of } \\
\text { disease }\end{array}$ & 15 & 62.5 & 11 & 64.7 & 14 & 82.3 & 10 & 76.9 & 48 & 67.6 \\
\hline Risk factors & 15 & 62.5 & 12 & 70.5 & 14 & 82.3 & 8 & 61.5 & 49 & 69.0 \\
\hline $\begin{array}{l}\text { Issues of LTC \& } \\
\text { HIV/AIDS }\end{array}$ & 8 & 33.3 & 6 & 35.2 & 6 & 35.2 & 3 & 23.0 & 23 & 32.3 \\
\hline HIV/AIDS in Elderly & 8 & 33.3 & 4 & 23.5 & 4 & 23.5 & 4 & 30.7 & 20 & 28.1 \\
\hline $\begin{array}{l}\text { Is staff required to } \\
\text { attend \% of } \\
\text { educational programs? }\end{array}$ & 22 & 91.6 & 17 & 100 & 16 & 94.1 & 12 & 92.3 & 67 & 94.3 \\
\hline $\begin{array}{l}\text { Is staff available with } \\
\text { sufficient knowledge } \\
\text { to educate others } \\
\text { about HIV/AIDS? }\end{array}$ & 21 & 87.5 & 15 & 88.2 & 14 & 82.3 & 12 & 92.3 & 62 & 87.3 \\
\hline
\end{tabular}

* Number of responses 


\section{$\underline{\text { Concerns }}$}

Table 4.6 shows the concerns that nursing facilities have about placement of HIV/AIDS infected individuals. All numbers and percentages shown represent the total number of facilities that indicated having concerns about placement of HIV/AIDS infect persons. Results indicate that the greatest concern nursing facilities have is the cost of caring for an infected person (57.7\%), followed by fear of infection from a resident or staff member (43.6\%). Other concerns for placement of an infected individual were confidentiality, a fear of exposure of certain diseases to AIDS patients with compromised health status, adequate longterm care planning, and lack of education about HIV/AIDS.

Region III and IV appear to have more concerns about placement of HIV/AIDS infected individuals. Region IV was especially concerned about staff turnover $(61.5 \%)$ and fear of community disapproval $(53.8 \%)$. Region III was particularly concerned about the cost of care $(70.5 \%)$ and fear of infection $(76.4 \%)$. Community disapproval was not a large issue for Region I (16.6\%). 
TABLE 4.6. PERCENTAGES \& FREQUENCIES OF "YES" REPSONSES TO FOLLOWING QUESTIONS REGARDING CONCERNS ABOUT HIV/AIDS IN WEST VIRGINIA NURSING FACILITES BY REGION

\begin{tabular}{|c|c|c|c|c|c|c|c|c|c|c|}
\hline \multirow[t]{2}{*}{ Question } & \multicolumn{2}{|c|}{ Region I } & \multicolumn{2}{|c|}{ Region II } & \multicolumn{2}{|c|}{ Region III } & \multicolumn{2}{|c|}{ Region IV } & \multicolumn{2}{|c|}{ Total } \\
\hline & $\mathrm{N}^{*}$ & $\%$ & $\mathrm{~N}$ & $\%$ & $\mathrm{~N}$ & $\%$ & $\mathrm{~N}$ & $\%$ & $\mathrm{~N}$ & $\%$ \\
\hline \multicolumn{11}{|c|}{ What are nursing facilities concerns about placement of HIV/AIDS infected individuals? } \\
\hline Cost of Care & 13 & 54.1 & 11 & 64.7 & 12 & 70.5 & 5 & 38.4 & 41 & 57.7 \\
\hline $\begin{array}{l}\text { Staff } \\
\text { turnover }\end{array}$ & 10 & 41.6 & 7 & 41.1 & 4 & 23.5 & 8 & 61.5 & 29 & 40.8 \\
\hline $\begin{array}{l}\text { Fear of } \\
\text { losing } \\
\text { potential } \\
\text { residents }\end{array}$ & 6 & 25.0 & 4 & 23.5 & 6 & 35.2 & 5 & 38.4 & 21 & 29.5 \\
\hline $\begin{array}{l}\text { Fear of } \\
\text { infection }\end{array}$ & 8 & 33.3 & 5 & 29.4 & 13 & 76.4 & 5 & 38.4 & 31 & 43.6 \\
\hline $\begin{array}{l}\text { Fear of } \\
\text { community } \\
\text { disapproval }\end{array}$ & 4 & 16.6 & 5 & 29.4 & 9 & 52.9 & 7 & 53.8 & 25 & 35.2 \\
\hline Other & 4 & 16.6 & 4 & 23.5 & 1 & 5.8 & 0 & 0 & 9 & 12.6 \\
\hline
\end{tabular}

\section{$\underline{\text { Resources }}$}

Table 4.7 shows the resources available to nursing facilities within each region and the ability of each nursing facility to care for HIV/AIDS infected individuals. All numbers and percentages shown represent the total number of facilities that indicated having resources available within the community to assist facilities in caring for HIV/AIDS infected individuals. The greatest resource available to participating facilities is the County Health Departments (84.5\%) followed by Hospice organizations $(71.8 \%)$, and the counseling services 
$(60.5 \%)$. Less than half of the facilities indicated having a HIV/AIDS organization or bereavement counseling service available to help support their facility in caring for infected individuals (43.6\%). Region II had considerably more HIV/AIDS organizations as a resource (82.3\%), compared to $43.6 \%$ overall.

Over half of the participating nursing facilities indicated they could meet the medical $(66.1 \%)$ and/or custodial (64.7\%) care needs of infected persons. Some facilities explained that they could only maintain short-term custodial care or that they did not provide custodial care, because they were a sub-acute unit of a hospital. Others only offered short-term care, but did not anticipate caring for AIDS patients because they would require more long-term care. Others facilities commented they were a hospital-based skilled nursing unit and would have no problems or anticipate no difficulties in providing care for an HIV/AIDS infected patient. Some facilities that have skilled units commented on having no problems with providing the medical needs, but they were not covered my Medicaid so they did not provide custodial needs. Some long-term care facilities noted that they were more concerned about having adequate knowledge to properly diagnosis the progression of the illness and to appropriately care for the medical needs of patient. They were not concerned about custodial care, and felt sure they could effectively meet the custodial care needs.

Region III appears to have more resources available to help care for infected individuals, but not necessarily an HIV/AIDS organization (43.6\%). Region IV facilities reported fewer available resources than other regions; particularly on the availability of an HIV/AIDS organization (15.3\%) and Bereavement counseling (15.3\%). 
TABLE 4.7. PERCENTAGES \& FREQUENCIES OF "YES" RESPONSES TO FOLLOWING QUESTIONS REGARDING RESOUCES AVAILABILITY SPECIFIC TO HIV/AIDS IN WEST VIRGINIA NURSING FACILITIES BY REGION

\begin{tabular}{|c|c|c|c|c|c|c|c|c|c|c|}
\hline \multirow[t]{2}{*}{ Question } & \multicolumn{2}{|c|}{ Region I } & \multicolumn{2}{|c|}{ Region II } & \multicolumn{2}{|c|}{ Region III } & \multicolumn{2}{|c|}{ Region IV } & \multicolumn{2}{|c|}{ Total } \\
\hline & $\mathbf{N} *$ & $\%$ & $\mathbf{N}$ & $\%$ & $\mathbf{N}$ & $\%$ & $\mathbf{N}$ & $\%$ & $\mathbf{N}$ & $\%$ \\
\hline \multicolumn{11}{|c|}{ What resources are available with the community to assist the facility in caring for HIV/AIDS infected person? } \\
\hline $\begin{array}{l}\text { County Health } \\
\text { Dept. }\end{array}$ & 19 & 79.1 & 14 & 82.3 & 16 & 94.1 & 11 & 84.6 & 60 & 84.5 \\
\hline $\begin{array}{l}\text { Counseling } \\
\text { Service }\end{array}$ & 14 & 58.3 & 12 & 70.5 & 12 & 70.5 & 5 & 38.4 & 43 & 60.5 \\
\hline Hospice & 18 & 75.0 & 11 & 64.7 & 15 & 88.2 & 7 & 53.8 & 51 & 71.8 \\
\hline $\begin{array}{l}\text { HIV/AIDS } \\
\text { organization }\end{array}$ & 9 & 37.5 & 14 & 82.3 & 6 & 35.2 & 2 & 15.3 & 31 & 43.6 \\
\hline $\begin{array}{l}\text { Bereavement } \\
\text { Counseling }\end{array}$ & 10 & 41.6 & 9 & 52.9 & 10 & 58.8 & 2 & 15.3 & 31 & 43.6 \\
\hline Other agencies & 2 & 83.3 & 3 & 17.6 & 1 & 5.8 & 0 & 0 & 6 & 8.4 \\
\hline \multicolumn{11}{|c|}{ Is nursing facility currently able to meet needs of HIV/AIDS infected persons? } \\
\hline Medical needs & 17 & 70.8 & 9 & 52.9 & 12 & 70.5 & 8 & 61.5 & 46 & 64.7 \\
\hline Custodial needs & 18 & 75.0 & 11 & 64.7 & 9 & 52.9 & 9 & 69.2 & 47 & 66.1 \\
\hline
\end{tabular}

* Number of responses

\section{Experiences}

Table 4.8 shows experiences in dealing with HIV/AIDS in each region. All numbers and percentages shown represent the total number of facilities that indicated having experience relating to issues of HIV/AIDS. Each facility was asked what experiences each had with issues relating to HIV/AIDS. Only $7 \%$ of all 71 participating facilities were currently caring for HIV/AIDS infected individuals. A total of 3 facilities were caring for only 1-2 patients; 1 facility was caring for 3-4 patients; and 1 was caring for more than 7 infected individuals. Only $9.8 \%$ reported that they had been asked to admit an infected individual and could not. Thus, over $80 \%$ of the facilities had not been approached to admit an HIV/AIDS 
resident. One facility explained that they were approached to admit and HIV-positive resident, but could not because the individual required IV pain medicine and antibiotics and their facility was not equipped for IV service. They are now equipped for simple IV service, but felt it is probably not sufficient enough to meet the complex needs of an HIV/AIDS infected patient. Other explanations included, no available beds, individual had no pay source, and unable to meet medical needs. When asked if facility would consider admission of HIV/AIDS infected individual $54.9 \%$ of the facilities answered "yes", $35.2 \%$ answered "maybe, depending on situation", and 7\% answered "no". One facility commented that the current knowledge level of staff about illness would be considered before admitting an infected person. No other explanations were given to explain why the admission of an HIV/AIDS infected individual would depend on the situation or why they would refuse to accept an infected person.

Only $8.4 \%$ of all participating facilities reported having incidents occur within their facility pertaining to HIV/AIDS. One facility specified that an HIV/AIDS resident had been admitted, and then expired while residing at the facility. This facility is not currently caring for any HIV/AIDS residents. Other incidents that occurred included needle sticks, an infected individual threatened to bite, spit or otherwise infect staff deliberately, and patient selfdisclosed illness to others in facility.

A total of only $1.4 \%$ of participating facilities reported having staff members quit if they had to care for HIV/AIDS infected persons, but $18.3 \%$ reported having staff threatened to quit. No explanations were given for why staff quit or threatened to quit. Out of the 6 facilities that reported having an incident occur within their facility relating to HIV/AIDS, only a third reported having an individual who quit or threatened to quit. 
More Region III facilities (76.4\%)reported they would consider admission of HIV/AIDS infected person compared to all participating facilities (54.9\%). Fewer Region I facilities would consider admission of an HIV/AIDS infected individual (37.5\%), which is less than the sample average of $54.9 \%$. 
TABLE 4.8. PERCENTAGES \& FREQUENCIES OF "YES" RESPONSES TO FOLLWING QUESTIONS REGARDING EXPERIENCES SPECIFIC TO HIV/AIDS IN WEST VIRGINIA NURSING FACILITIES BY REGION.

\begin{tabular}{|c|c|c|c|c|c|c|c|c|c|c|}
\hline \multirow[t]{2}{*}{ Question } & \multicolumn{2}{|c|}{ Region I } & \multicolumn{2}{|c|}{ Region II } & \multicolumn{2}{|c|}{ Region III } & \multicolumn{2}{|c|}{ Region IV } & \multicolumn{2}{|c|}{ Total } \\
\hline & $\mathbf{N}^{*}$ & $\%$ & $\mathbf{N}$ & $\%$ & $\mathbf{N}$ & $\%$ & $\mathbf{N}$ & $\%$ & $\mathbf{N}$ & $\%$ \\
\hline $\begin{array}{l}\text { Is facility currently } \\
\text { caring for } \\
\text { HIV/AIDS pt.? }\end{array}$ & 2 & 8.3 & 1 & 5.8 & 2 & 11.7 & 0 & 0 & 5 & 7.0 \\
\hline $\begin{array}{l}\text { If no, has facility } \\
\text { been asked to take } \\
\text { infected patient } \\
\text { and could not? }\end{array}$ & 0 & 0 & 4 & 23.5 & 0 & 0 & 3 & 23.0 & 7 & 9.8 \\
\hline $\begin{array}{l}\text { Would facility } \\
\text { consider admission } \\
\text { of HIV/AIDS } \\
\text { person? }\end{array}$ & 9 & 37.5 & 10 & 58.8 & 13 & 76.4 & 7 & 53.8 & 39 & 54.9 \\
\hline $\begin{array}{l}\text { Have any incidents } \\
\text { occurred in facility } \\
\text { related to } \\
\text { HIV/AIDS? }\end{array}$ & 0 & 0 & 4 & 23.5 & 1 & 5.8 & 1 & 7.6 & 6 & 8.4 \\
\hline $\begin{array}{l}\text { Has staff quit } \\
\text { because they had } \\
\text { to work with } \\
\text { HIV/AIDS pt.? }\end{array}$ & 0 & 0 & 0 & 0 & 0 & 0 & 1 & 7.6 & 1 & 1.4 \\
\hline $\begin{array}{l}\text { Have staff every } \\
\text { threatened to quit? }\end{array}$ & 4 & 16.6 & 2 & 11.7 & 4 & 23.5 & 3 & 23.0 & 13 & 18.3 \\
\hline
\end{tabular}


$\underline{\text { Bivariate Analysis }}$

\section{$\underline{\text { Policies and Procedures }}$}

Table 4.9 shows the relationship between policies and procedures and the number of beds in each facility. (refer to table 4.2 for the number of beds by total population and response rate, and table 4.3 for the number of beds by total number of facilities in each region and total number of participating facilities in each region.) The likelihood ratio of prob $>$ chisq value (P-Value) of 0.5 will be used to establish significance.

The data shows two policies and procedures associated with size of nursing facility. Larger facilities ( $>90$ beds) tend to have more written procedures on admission and/or care of special needs residents other than HIV/AIDS infected individuals $(\mathrm{p}=.04)$ and smaller nursing facilities tend to offer more testing to staff $(\mathrm{p}=.01)$. 
TABLE 4.9. PECENTAGES \& FREQUENCIES OF "YES” RESPONSES TO FOLLOWING QUESTIONS REGARDING POLICIES \& PROCEDURES SPECIFIC TO HIV/AIDS IN WEST VIRGINIA NURSING FACILITIES BY SIZE OF FACILITY

\begin{tabular}{|c|c|c|c|c|c|}
\hline \multirow[t]{2}{*}{ Question } & \multicolumn{2}{|c|}{$\leq 90$ Beds } & \multicolumn{2}{|c|}{$>90$ Beds } & \multirow[t]{2}{*}{ P-Value } \\
\hline & $\mathbf{N}^{*}$ & $\%$ & $\mathbf{N}$ & $\%$ & \\
\hline $\begin{array}{l}\text { Written policy for admission of HIV/AIDS } \\
\text { pt.** }\end{array}$ & 8 & 20.0 & 7 & 23.3 & 0.6 \\
\hline $\begin{array}{l}\text { Written procedures for admission of } \\
\text { HIV/AIDS pt. }\end{array}$ & 7 & 17.5 & 7 & 23.3 & 0.6 \\
\hline Written policy for care of HIV/AIDS pt. & 10 & 25.0 & 10 & 33.3 & 0.5 \\
\hline $\begin{array}{l}\text { Written procedure for care of HIV/AIDS } \\
\text { pt. }\end{array}$ & 10 & 25.0 & 10 & 33.3 & 0.6 \\
\hline Written policy on communicable disease & 39 & 97.5 & 30 & 100 & 0.13 \\
\hline $\begin{array}{l}\text { Written procedure on special needs } \\
\text { resident pt. }\end{array}$ & 20 & 50.0 & 22 & 73.3 & 0.04 \\
\hline $\begin{array}{l}\text { Written policy for persons providing direct } \\
\text { care }\end{array}$ & 5 & 12.5 & 3 & 10.0 & 0.16 \\
\hline Does NH offer AIDS testing to staff? & 30 & 75.0 & 14 & 46.6 & 0.01 \\
\hline Does NH offer AIDS testing to residents? & 26 & 65.0 & 19 & 63.3 & 0.52 \\
\hline
\end{tabular}

\section{$\underline{\text { Education }}$}

Table 4.1.1 shows the relationship between the type and content of educational programs and the number of beds in each facility. There was an association between nursing home staff being required to attend educational programs, and an availability of staff with sufficient knowledge about HIV/AIDS, but there was little variation in response to these 
questions. There are no other significant differences in the number of beds in facilities and the type and content of educational/inservice programs.

TABLE 4.1.1. PERCENTAGES \& FREQUENICES OF “YES” RESPONSES TO FOLLWING QUESTIONS REGARDING EDUCATION SPECIFIC TO HIV/AIDS IN WEST VIRGINIA NURSING

FACILITIES BY SIZE OF FACILITY

\begin{tabular}{|c|c|c|c|c|c|}
\hline \multirow[t]{2}{*}{ Question } & \multicolumn{2}{|c|}{$\leq 90$ Beds } & \multicolumn{2}{|c|}{$>90$ Beds } & \multirow[t]{2}{*}{ P-Value } \\
\hline & $\mathbf{N}^{*}$ & $\%$ & $\mathbf{N}$ & $\%$ & \\
\hline \multicolumn{6}{|c|}{ Does nursing facility offer educational programs about: } \\
\hline HIV/AIDS & 29 & 72.5 & 21 & 70.0 & 0.7 \\
\hline Sexuality & 12 & 30.0 & 10 & 33.3 & 0.8 \\
\hline Drug use $\&$ abuse & 17 & 42.5 & 11 & 36.6 & 0.5 \\
\hline \multicolumn{6}{|c|}{ Do educational programs on HIV/AIDS including information about: } \\
\hline Transmission of disease & 29 & 72.5 & 20 & 66.6 & 0.5 \\
\hline Risk factors & 27 & 67.5 & 21 & 70.0 & 0.9 \\
\hline Issues of LTC \& HIV/AIDS & 10 & 25.0 & 12 & 40.0 & 0.2 \\
\hline HIV/AIDS in the Elderly & 10 & 25.0 & 9 & 30.0 & 0.5 \\
\hline $\begin{array}{l}\text { Is staff required to attend } \% \text { of educational } \\
\text { programs? }\end{array}$ & 36 & 90.0 & 30 & 100.0 & 0.03 \\
\hline $\begin{array}{l}\text { Is staff available with sufficient knowledge } \\
\text { to educate others about HIV/AIDS? }\end{array}$ & 32 & 80.0 & 29 & 96.6 & 0.03 \\
\hline
\end{tabular}




\section{Concerns}

Table 4.1.2 shows the relationship between the concerns about placement of an infected individual and the size of the nursing facility. There are no significant relationships, but there is a tendency for smaller facilities to be more concerned about community disapproval $(\mathrm{p}=.08)$.

TABLE 4.1.2. PERCENTAGES \& FREQUENCIES OF "YES" RESPONSES TO FOLLOWING QUESTIONS REGARDING CONCERNS ABOUT HIV/AIDS IN WEST VIRGINIA NURSING FACILITIES BY SIZE OF FACILITY

\begin{tabular}{|c|c|c|c|c|c|}
\hline \multirow[t]{2}{*}{ Question } & \multicolumn{2}{|c|}{$\leq 90$ Beds } & \multicolumn{2}{|c|}{$>90$ Beds } & \multirow[t]{2}{*}{ P-Value } \\
\hline & $\mathbf{N}^{*}$ & $\%$ & $\mathbf{N}$ & $\%$ & \\
\hline \multicolumn{6}{|c|}{ What are nursing facilities concerns about placement of HIV/AIDS infected individuals? } \\
\hline Cost of care & 24 & 60.0 & 16 & 53.3 & 0.6 \\
\hline Staff turnover & 13 & 32.5 & 15 & 50.0 & 0.15 \\
\hline Fear of losing potential residents & 12 & 30.0 & 8 & 26.6 & 0.6 \\
\hline Fear of infection & 20 & 50.0 & 10 & 33.3 & 0.15 \\
\hline Fear of community disapproval & 17 & 42.5 & 7 & 23.3 & 0.08 \\
\hline Other & 3 & 7.5 & 6 & 20.0 & 0.11 \\
\hline
\end{tabular}

\section{$\underline{\text { Resources }}$}

Table 4.1.3 shows the relationship between the resources available in the community and the number of beds in each facility. There were no significant differences between the available resources and the number of beds in the facilities. 
TABLE 4.1.3. PERCENTAGES \& FREQUENCIES OF "YES" RESPONSES TO FOLLOWING QUESTIONS REGARDING RESOURCE AVAILABILITY SPECIFIC TO HIV/AIDS TO WEST VIRGINIA NURSING FACILITIES BY SIZE OF FACITIY

\begin{tabular}{|c|c|c|c|c|c|}
\hline \multirow[t]{2}{*}{ Question } & \multicolumn{2}{|c|}{$\leq 90$ Beds } & \multicolumn{2}{|c|}{$>90$ Beds } & \multirow[t]{2}{*}{ P-Value } \\
\hline & $\mathbf{N}^{*}$ & $\%$ & $\mathbf{N}$ & $\%$ & \\
\hline \multicolumn{6}{|c|}{$\begin{array}{l}\text { What resources are available within the community to assist the facility in caring for HIV infected } \\
\text { persons? }\end{array}$} \\
\hline County Health Dept. & 35 & 87.5 & 25 & 83.3 & 0.7 \\
\hline Counseling Services & 23 & 57.5 & 20 & 66.6 & 0.4 \\
\hline Hospice & 30 & 75.0 & 20 & 66.6 & 0.5 \\
\hline HIV/AIDS organization & 15 & 37.5 & 16 & 53.3 & 0.13 \\
\hline Bereavement Counseling & 18 & 45.0 & 12 & 40.0 & 0.5 \\
\hline Other agencies & 2 & 5.0 & 4 & 1.3 & 0.2 \\
\hline \multicolumn{6}{|c|}{ Is nursing facility currently able to meet needs of HIV/AIDS infected persons? } \\
\hline Medical needs & 24 & 60.0 & 22 & 73.3 & 0.4 \\
\hline Custodial needs & 24 & 60.0 & 22 & 73.3 & 0.4 \\
\hline
\end{tabular}

Experiences

Table 4.1.4 shows the relationship between the experiences in nursing facilities specific to HIV/AIDS and the size of the nursing facility. There were no significant relationships between experience and nursing facility size, but there was a tendency for facilities that are currently caring for HIV/AIDS infected patients and those facilities that have been asked to accept infected individual and could not to be the larger ones. However, these numbers were too low to attribute much significance to this. 
TABLE 4.1.4 PERCENTAGES \& FREQUENICES OF "YES” RESPONSES TO FOLLOWING QUESTIONS REGARDING EXPERIENCES SPECIFIC TO HIV/AIDS IN WEST VIRGINIA NURSING FACILITIES BY SIZE OF FACILITY

\begin{tabular}{|c|c|c|c|c|c|}
\hline \multirow[t]{2}{*}{ Question } & \multicolumn{2}{|c|}{$\leq \mathbf{9 0}$} & \multicolumn{2}{|c|}{$>90$} & \multirow[t]{2}{*}{ P-Value } \\
\hline & $\mathbf{N}^{*}$ & $\%$ & $\mathbf{N}$ & $\%$ & \\
\hline $\begin{array}{l}\text { Is facility currently caring for HIV/AIDS } \\
\text { pt.?** }\end{array}$ & 1 & 2.5 & 4 & 13.3 & 0.103 \\
\hline $\begin{array}{l}\text { If no, has facility been asked to take } \\
\text { infected pt. and could not? }\end{array}$ & 3 & 7.5 & 4 & 13.3 & 0.09 \\
\hline $\begin{array}{l}\text { Would facility consider admission of } \\
\text { HIV/AIDS person? }\end{array}$ & 20 & 50.0 & 19 & 63.3 & 0.6 \\
\hline $\begin{array}{l}\text { Have any incidents occurred in facility } \\
\text { related to HIV/AIDS? }\end{array}$ & 2 & 5.0 & 4 & 13.3 & 0.4 \\
\hline $\begin{array}{l}\text { Has staff quit because they had to work } \\
\text { with HIV/AIDS pt.? }\end{array}$ & 1 & 2.5 & 0 & 0 & 0.5 \\
\hline Have staff every threatened to quit? & 9 & 22.5 & 4 & 13.3 & \\
\hline
\end{tabular}




\section{CHAPTER 5: DISCUSSION}

$\underline{\text { Major Findings }}$

$\underline{\text { Policies and Procedures }}$

Less than half of participating facilities indicated an admission/care policy and/or procedure specific to HIV/AIDS. Almost all nursing facilities indicated a communicable disease policy, but not all indicated it included HIV/AIDS. Many facilities indicated that Universal precautions were considered a substitute for a specific written procedure on HIV/AIDS. This was consistent with the findings of Crossley and colleagues (1992). In this study most facilities explained that the state required Universal Precautions in all of their institutions and that the federal law, which prohibited discrimination against HIV/AIDS infected patients, constituted their policy. Significance shows larger facilities had more written procedures about care of special needs residents, other than HIV/AIDS infected patients, and smaller facilities offered more HIV/AIDS testing to staff. It is unclear why testing was higher in these facilities.

Region I facilities reported having more polices and procedures overall involving issues of HIV/AIDS. This may be due to the geographical location of the region. It is the northern most region of West Virginia located between Ohio and Pennsylvania, and includes the largest number of state colleges and universities. Individuals in this region may be more exposed to HIV/AIDS issues and may encounter a wider range of illnesses and diseases. 


\section{$\underline{\text { Education }}$}

Most of the participating facilities reported they offered educational programs on HIV/AIDS. However, most facilities did not offer educational programs on sexuality/same sex issues and drug use and abuse. Both are high-risk activities for infection of HIV/AIDS. Facilities may not consider this a large issue because of the low percentage of HIV/AIDS infected individual within the state, and the low population of high-risk individuals, as compared to more urban areas of the country. Most educational programs about HIV/AIDS included transmission of disease and risk factors, but few included issues of long-term care and AIDS and HIV/AIDS in the elderly.

\section{$\underline{\text { Concerns }}$}

Over half of the participating facilities reported the cost of care $(57.5 \%)$ as the greatest concern for placement of an HIV/AIDS infected person. This may be due to the high percentage of HIV/AIDS infected persons relying on Medicaid. Region III had a higher than average response rate for the cost of care and the fear of infection. Region I had less concern for the fear of community disapproval compared to other regions. Again, this may be due to the region having more access to larger cities, and more exposure to HIV/AIDS issues, which may make the community more comfortable with the disease or because they are more of a transient population with West Virginia University and other colleges and federal worksites in the area. These results are similar to another study that found reasons most facilities in the Chicago area refused to admit nursing home residents was due to the possible decrease in staff recruitment, decrease in referrals, and the cost of caring for the infected individuals (Linsk et al., 1993). Smaller facilities had a higher percentage of fear of community disapproval as a 
concern of placement. Again, this may be due to smaller facilities being located in more rural areas of West Virginia with less exposure to HIV/AIDS issues. Region IV, the most rural area of West Virginia, had a higher than average response for staff turnover as a concern for placement. The percentage of eligible employees and education level in this region may be lower than average.

\section{$\underline{\text { Resources }}$}

For most nursing facilities, the County Health Departments were the most available resource to assist with the care of HIV/AIDS infected individuals. Region III reported having the most resources available to them over all. It is unclear why Region III would have more resources available, but it is speculated that because they reported currently caring for HIV/AIDS infected individuals and more educational efforts were reported by this region there may be more of an attempt to recognize outside agencies. Region II reported having more HIV/AIDS organizations available in their area as a resource. This may be because this area includes the largest city in the state, Charleston, which is the home for most of the state agencies and programs.

\section{$\underline{\text { Experiences }}$}

Few participating facilities indicated currently caring for HIV/AIDS infected persons, or having been approached to care for an infected individual. This is similar to the 1988 Wisconsin Department of Health and Social Services study, which also found a low percentage of nursing homes being approached to admit patients (Linsk et al., 1993). Since few facilities are caring for infected persons, and few have been asked to admit them the 
recognition of care needs is not urgent and may explain responses in this study. Therefore, facilities are not as attentive of the need for facility awareness, and do only what is necessary by law to fulfill HIV/AIDS specific requirements.

Slightly more than half of the 72 facilities indicated they would accept an HIV/AIDS infected person. A larger percentage of facilities in Region III reported they would accept an HIV/AIDS infected individual compared to the other regions and overall. This may be due to Region III reporting more educational programs and resources available within their community to help them care for infected individual. Fewer of Region I facilities reported they would consider admission of an HIV/AIDS patient. This region also ranked below average on HIV/AIDS education, and below average on resources available to them within the community. There were no significant relationships between the size of the facility and the experiences of each.

\section{Organizational Stage by Nursing Facility}

Stage 1: Sensing of unsatisfied demands on the system, looks at the amount of concerns, incidents, and difficulties in nursing homes resulting from HIV/AIDS related issues. A majority were concerned about placement of infected individuals, but little incidents or difficulties caused by staff were reported. Few facilities reported having a staff member threatened to quit due to the issue of caring for infected persons, and even less reported having a staff member actually quit. Overall, most facilities in this stage are sensing concerns about placement, but have had little incidents or difficulties occur.

Stage 2: Search for possible responses, looks at what is currently being done, or not being done within each facility to prepare for the HIV/AIDS population. It recognizes only 
facilities that have minimal/no policies and procedures specific to HIV/AIDS, and minimal/no educational programs. Less than $1 / 3$ of all participating facilities had policies and procedures established specific to HIV/AIDS. However, most facilities reported offering HIV/AIDS educational programs.

Stage 3: Evaluation of alternatives, looks at what resources are available within the community, if nursing homes would consider admission of infected individuals, and if nursing homes are able to meet medical and custodial care in infected residents. A majority of all facilities have some type of resource available to them. Most indicated they would consider admission of an infected person, and reported they could meet the custodial needs and medical needs of infected residents. Overall, most participating facilities appear to be in this stage of the organizational change theory due to the recognition of resource availability, consideration of admission, and ability to provide care.

Stage 4: Decision to adopt a course of action, looks at the current policies and procedures, educational programs, and if facility is currently caring for infected person. Most facilities located in this stage should already have policies, procedures, and educational programs established. They may or may not be caring for an infected individual. Again, less than one-third of the facilities have polices and procedures in place specifically related to HIV/AIDS, and few facilities are caring for HIV/AIDS infected person.

It appears that most West Virginia facilities are in the third stage of organizational change. The have sensed unsatisfactory demands, search for possible response, and are evaluating the alternatives. They have not effective made a decision to adopt a course of action. 


\section{$\underline{\text { Study Limitations }}$}

There are several limitations to this study. The data for this study was collected by selfreport so there is no evidence that events or situations actually occurred and there can be recall bias. Although, all surveys were sent to the Social Services Director at each facility it is unknown who actually completed the questionnaire. It was encouraged to be a group effort, possibly involving the Administrator, Director of Nursing, and Inservice Coordinator, but in most cases it is likely that not all administrative personal were included. The facilities were not monitored prior to the survey distribution so it quite possible that some nursing facilities, especially the larger facilities, would have several Social Service workers. Often the title of Social Services Director is substituted for Admission Coordinator. Thus, it is possible that a social worker, or other staff member, with limited knowledge of the situation regarding HIV/AIDS in the nursing facility may have completed the survey.

The facilities surveyed only included all certified nursing homes within the state of West Virginia, so findings may not be representative of all facilities that care for older persons. A list of certified facilities was obtained from the Nursing Home Board of Licensure and Certification. Thus, the study is not representative of the personal care homes within the state. The personal care homes, which number over 300 in West Virginia, are not certified nursing facilities, but are usually privately owned care homes. (Personal communications with Personal Care Home owner, October 1999). These facilities may have different experiences than the certified facilities.

Another limitation of this study is there was no information on the age of the nursing home residents. In an attempt to simplify the survey, questions about age differences in the nursing home population were excluded. The literatures shows that one of the barriers to 
nursing home care for HIV/AIDS infected individuals is the differences in the age of infected persons and the average age of nursing home residents (Linsk et al., 1993). If the survey could have addressed the issues of age, such as, does the nursing facilities have a reputation of admitting younger residents?, what age ranges are the current residents within the facility?, would nursing facility consider admission of younger resident as concern for the facility?, and/or if caring for HIV/AIDS infected persons what is the age or what are the age ranges for those residents?. These questions may have answered concerns regarding the age ranges for facilities that are currently caring for HIV/AIDS issues.

\section{$\underline{\text { Implications for Community Health Promotion }}$}

This study shows a need for education of disease progression, HIV/AIDS in the elderly, issues of long-term care and HIV/AIDS, and establishment of policies and procedures specific to HIV/AIDS in nursing facilities in West Virginia. Most facilities indicated the need

for education in at least one aspect of the survey. A 1988 study by John M. Heath explained the steps that a New York City nursing facility took toward preparing to admit HIV/AIDS infected persons on a trail basis. After the trial session, the staff recognized the educational programs as the single most advantage to providing adequate care to the infected residents (Heath, 1998). Facilities indicated the need for education in many different ways. Some survey participants explained,

"It is our belief that the majority of nursing homes would be capable of meeting the needs of HIV/AIDS residents if proper staff education were provided. Most nursing homes, in our belief, are not adequately informed of the medical condition to currently provide QUALITY care for these residents. Knowledge of the illness progression, symptomatic issues, and psychosocial concerns needs to be in place before proper care can be given. Simply following universal precautions is not enough." 
"Lack of education and understanding of HIV/AIDS among nursing assistants, housekeeping, laundry, activities, and dietary personnel."

"The need continues to exist to expand the knowledge of risk factors associated with the virus."

The educational programs about HIV/AIDS in the elderly and issue of long-term care and HIV/AIDS may help alert staff to the possibility of caring for infected residents. More education about the progression of the disease may help staff decide if they are able to meet the care needs of an HIV/AIDS infected resident. Some facilities may be able to provide only short-term care, and/or may require assistance from outside agencies when the individual's illnesses become harder to manage. Education about resource availability, and the establishment of HIV/AIDS specific policies and procedures becomes very important when facilities are considering admission of HIV/AIDS infected person. Many facilities may not take the initiative to implement policies and procedures or to increase the amount of education until an incident occurs within the home. Most facilities are using only the state mandated policies for communicable disease and universal precautions to care for all individuals, including HIV/AIDS infected persons. Although, these policies are sufficient enough to prevent transmission of a wide range of disease and illness they are not specific enough to incorporate the extensive care needs that infected residents may require. Facilities may be more prone to accept the individual if policies, procedures, and resources are available.

Due to the rural nature of the state, an intervention to reach all certified facilities may be challenging. Many facilities have to travel hours to attend nursing facility specific programs, such as, workshops and continuing education. An interesting intervention may be to offer 
helpful information over the internet. However, internet service is currently not available in all areas of West Virginia. These areas may require more one-on-one attention. An intervention involving the county health departments may be more appropriate, since most facilities recognize them as a resource within the community. It is difficult to tell what type of intervention would be most appropriate for all facilities. West Virginia facilities are not ignoring the issue of HIV/AIDS, but they also are not putting a lot of emphases on preparing for the possibility of the admission of an infected individual. 


\section{REFERENCES}

Babbie, E., Wagenaar, T.C., (1989). The Practice of Social Research (5). Beauparlant, S., Emori, J. Belmont, California. Wadsworth Publishing Company.

Crossley, K., Nelson, L., Irvine, P. (1992). State Regulations Governing Infection Control Issues in Long-Term Care. Journal of the American Geriatric Society, 40, 251-254.

Department of Health and Human Resources Division of Health. (1997, August). West $\underline{\text { Virginia Division of Health Legislative Rules Title 64, Series } 13 \text { Nursing Home Licensure }}$ Rule.

Department of Health and Human Resources Bureau For Public Health, Office of Epidemiology and health Promotion, Division of Surveillance and Disease Control. (1998). Epidemiologic Profile of HIV/AIDS in West Virginia.

Emlet, C.A. (1997, April). HIV/AIDS in the Elderly. Home Care Provider, 2, $69-75$.

Fogarty, T.E., Gentry, D., Lehrman, S.E. (1997). Defining the Challenges of Providing LongTerm Care: The Case of the Nursing Home Industry's Response to the AIDS Epidemic. Journal of Aging \& Social Policy, 9, 33-49.

Freeman, I.C. (1988). Caring for Persons with AIDS in Geriatric Nursing Homes. Health and Social Work, $156-158$.

Heath, J.M. (1998, June). Care of Persons With AIDS in the Nursing Home. Family $\underline{\text { Medicine, }}$ 30, 436-440. 


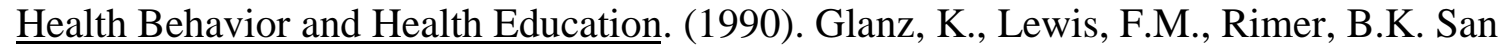
Francisco, California: Jossey-Bass Inc., Publishers.

Linsk, N.L., Cich, P.J., Cianfrani, L. (1993, January). The AIDS Epidemic: Challenges for Nursing Homes. Journal of Gerontological Nursing, 19, 11-22.

MacDowell, N.M. (1989). Willingness to Provide Care to AIDS Patients in Ohio Nursing Homes. Journal of Community Health, 14, 205-213.

\section{WEBSITES}

US Census Bureau United State Department of Commerce:

http://www.census.gov/population/www/projections/popproj.html

American Health Care Association, The Looming Crisis: Profile: Nursing Home Resident: http://www.ahca.org/secure/nfres.htm 


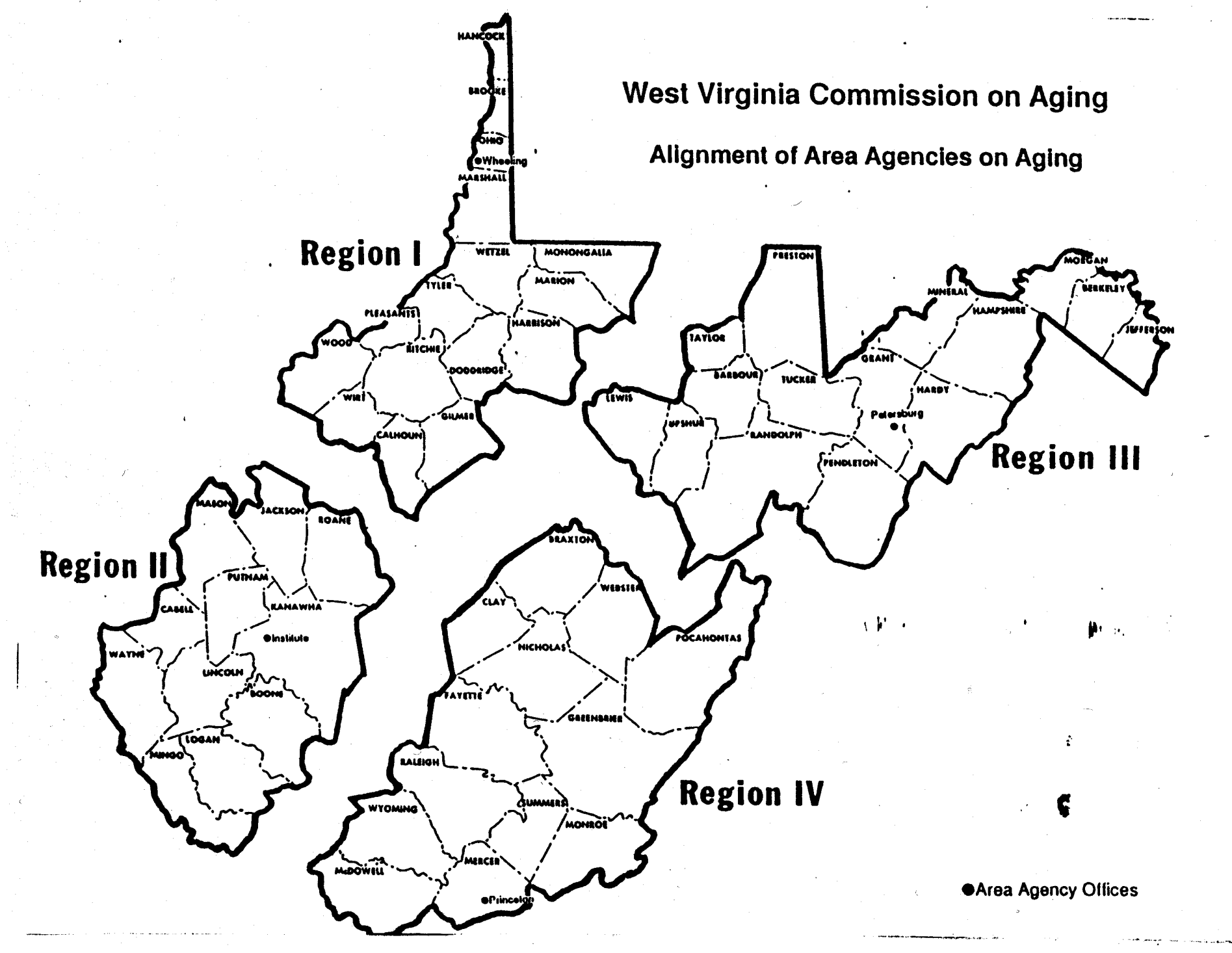




\section{APPENDIX B: $\mathbf{1}^{\text {st }}$ Cover Letter}

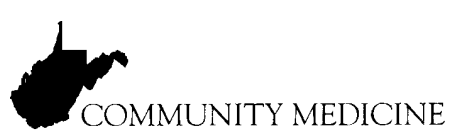

WIST VIRGINIA UNIVERSTTY

Institution Review Board for the Protection of Human Research Subjects

October 14,1999

Dear Social Services Director:

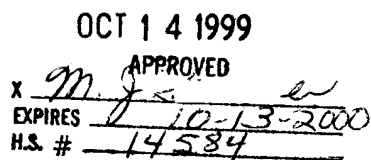

Introduction: I am conducting a statewide survey entitled, A Look At HIV/AIDS In West Virginia Nursing Homes, to leam more about how prepared West Virginia nursing facilities are to deal with the HIV/AIDS epidemic. Similar studies have been conducted in other states, such as, Pennsylvania and Ohio, but these studies were done much eartier on in the AIDS epidemic and yielded results that showed that nursing homes were not prepared to deal with issues of HIV/AIDS. Now, approximately 15 years after the beginning of the epidemic, this study will give us valuable information about the readiness of West Virginia nursing facilities regarding the admission and care of HIV/AIDS infected individuals into primarily geriatric long-term care facilities. Various State agencies have been informed of this study. These agencies include the State Ombudsman Program, State AIDS Prevention Program, State Board of Licensure \& Certification, and the West Virginia Health Care Association. Upon completion of this study a copy of the results will be sent to all mursing facilities, as well as to various agencies within the state. Results will yield the readiness to change of West Virginia mursing facilities as a whole, not as individual facilities.

This research is being done to fulfill requirements for a master's thesis.

Description of Procedures: You have been asked to participate in this survey by completing the enclosed questionnaire. All I 44 nursing facilities within the state of West Virginia will be surveyed. This survey is proposed to gain an organizational perspective of each facility, and not an individual viewpoint. All Social Services Directors at each facility have been designated as the key informant, but completion of the survey is encouraged to be a group effort, possibly including the Administrator, Director of Nursing, and Inservice Coordinator. This is an anonymous survey. Please do not write your name or facility's name on any part of this survey. A self-addressed, stamped ervelope has been provided for use in returning the survey. Also, included is a map from the West Virginia Commission on Aging that designates the counties and regions throughout the state. Use this map to assist you in locating the region of your nursing facility. This survey should take about 10-15 minutes to fill out.

Risks, Discomforts, and Benefits: There are no known or expected risks from participating in this study, and it is not expected to be of direct benefit to you as an individual facility. The knowledge gained may be of benefit to all nursing facilities, health care professionals, and other agencies throughout the state.

Voluntary Participation and Anonymity: Participation is entirely voluntary. The information you provide will be used for data analysis purposes only. This is an anonymous survey, therefore, no names of nursing facilities will be known. All data will be strictly confidential and will not be disclosed or released to others. Personnel from state or federal agencies will not have access to this data. As a research participant you may decline to answer any specific question. 
APPENDIX B: $1^{\text {st }}$ Cover Letter, page 2

\section{"A Look At HIV/AIDS In West Virginia Nursing Homes" page 2}

Consent to Participate and Contact person: Your return of the completed questionnaire will be considered your consent to participate. After completing the questionnaire please return it in the enclosed emvelope as soon as possible. Please feel free to contact me, Valarie Bell, or my thesis chair, Dr. Irene Tessaro, at the numbers listed below or email me if you have any questions about this survey. If you have questions concerning your rights as a subject of research, you may contact the executive secretary of the Institutional Review Board at West Virginia University at 304-293-7073.

Your help and time are appreciated.

Valarie A. Bell

Master's Thesis Student

West Virginia University

(304) 366-7533

talarie@prodigy net

Dr. Irene Tessaro, MA, MSN, DrPH

Associate Professor, Dept. of Community Medicine

Thesis Committee Chair

West Virginia University

P.O Box 6116

Morgantown, WV 26506-6II6

(304) 293-7510 ext. 5211 


\section{APPENDIX C: $2^{\text {nd }}$ Cover Letter}

\section{Robert C. Byrd Health Sciences Center \\ of West Virginia University \\ Department of Community Medicine}

October 29, 1999

Dear Social Services Director:

Introduction: I am conducting a statewide survey entitled, A Look At HIV/AIDS In West Virginia Nursing Homes, to learn more about how prepared West Virginia nursing facilities are to deal with the HIV/AIDS epidemic. This survey was originally sent out on October 14,1999 . If you received a copy and have already responded, thank you. If you did not receive a survey, or if you misplaced your first copy please use the enclosed second copy to respond. Upon completion of this study a copy of the results will be provided to each nursing facility within the state, and to various state agencies. A list of state agency representatives who are supporting this study can be found at the bottom of this letter.

Background: This study will give us valuable information about the readiness of West Virginia nursing facilities regarding the admission and care of HIV/AIDS infected individuals into primarily geriatric long-term care facilities. This study is being done to fulfill requirements for a master's thesis.

Description of Procedures: You have been asked to participate in this study by completing the enclosed questionnaire. All 144 certified nursing facilities within the state of West Virginia will be surveyed. This survey is proposed to gain an organizational perspective of each facility, and not an individual viewpoint. All Social Services Directors at each facility have been designated as the key informant, but completion of the survey is encouraged to be a group effort, possibly including the Administrator, Director of Nursing, and Inservice Coordinator. This is an anonymous survey. Please do not write your name or facility's name on any part of this survey. A self-addressed, return postage paid envelope has been provided for use in returning the survey. Also, included is a map from the West Virginia Commission on Aging that designates the counties and regions throughout the state. Use this map to assist you in locating the region of your nursing facility. This survey should take about 10-15 minutes to complete.

Voluntary Participation and Consent to Participate: Participation is entirely voluntary. The information you provide will be used for data analysis purposes only. This is an anonymous survey, therefore, no names of nursing facilities will be known. Your return of the completed questionnaire will be considered your consent to participate. Please feel free to contact me, Valarie Bell, or my thesis chair, Dr. Irene Tessaro, at the numbers listed below or email me if you have any questions about this survey. If you have any questions about your rights as a subject of research, you may contact the executive secretary of the Institutional Review Board at West Virginia University at 304-293-7073.

Your help is appreciated.

The following is a list of state agency representative who support this study.

VP West Virginia Health Care Association, John Alfano

West Virginia State Ombudsman, Larry Medley

West Virginia State AIDS Program, Loretta Haddy

Valarie A. Bell

Master's Thesis Student

West Virginia University

304-366-7533
Dr. Irene Tessaro, MA, MSN, DrPH

Associate Professor, Dept. of Community Medicine West Virginia University 304-293-7510 ext.5211

Educational Programs in Community and Public Health 


\section{A Look At HIV/AIDS In West Virginia Nursing Homes}

The following is a survey that addresses issues relating to HIV/AIDS in West Virginia nursing homes. This is an anonymous survey, please do not write your name or facilities names on this questionnaire. When answering questions, please answer completely and to the best of your knowledge. This is an organizational survey, all answers should be from an organizations perspective and not an individuals.

\section{Organizational Factors}

1. Total number of beds in facility:

2. Region in which facility is located: (use map provided to help designate your region.)

\section{Policy}

3. Does nursing facility have a specific written policy regarding: (please check all that apply)

_ Admission of HIVIAIDS infected individuals

— Care of HIVIAIDS infected individuals

_ Communicable diseases

4. If you did not check admission of HIVIAIDS infected individuals, but checked communicable diseases, does the communicable disease policy include HIVIAIDS infected individuals?

$$
\begin{aligned}
& \text { Yes } \\
& \text { - No } \\
& \text { — Don't know }
\end{aligned}
$$

5. Does nursing facility have a written policy stating that those individuals who are providing direct care to an HIVIAIDS infected person within the facility are to be informed of his/her illness?

$$
\begin{aligned}
& \text { Yes } \\
& \text { _ No }
\end{aligned}
$$

6. If an HIVIAIDS infected individual is admitted into the nursing home, who would be informed of the individuals illness? (check all that apply)

Administrator

Social Services Director

_ Medical Director of facility

_ Director of Nursing
RN's and LPN's

Certified Nursing Assistants

Activities Directors

_Other staff: 
7. Does nursing facility offer HIVIAIDS testing to staff?

Yes
No

8. Does nursing facility offer HIVIAIDS testing to residents?

Yes
- No

\section{Procedures}

9. Does nursing facility have specific written procedures regarding: (please check all that apply)

Admission of HIVIAIDS infected individual

_ Care of HIVIAIDS infected individual

_ Admission and lor care of special needs resident, other than HIVIAIDS infected individuals

10. If you did not check one of the above procedures, would Universal Precautions be considered a substitute for a specific written procedure?

- Yes

- No

_ Don't know

11. Is it easy to make changes in nursing home procedures?

$$
\begin{aligned}
& \text { Yes } \\
& \text { _ Somewhat } \\
& \text { _ No }
\end{aligned}
$$

12. Are nursing staff usually open to new ways of doing things within facility?

$$
\begin{aligned}
& \text { Yes } \\
& \text { - Somewhat } \\
& \text { _ No }
\end{aligned}
$$

\section{Education}

13. Does nursing facility offer educational programs about: (please check all that apply) HIVIAIDS

_ Sexuality, including same sex issues

_ Drug use and addiction

14. If you checked one of the programs above, are these programs offered:

_ Annually

_ Quarterly
_Monthly On request

_Other: 
15. If educational programs on HIVIAIDS are offered does information include: (please check all that apply)

Transmission of disease _Risk Factors
_Issues of long-term care and the HIV population

_Education about HIVIAIDS in elderly

16. Is the nursing home staff required to attend a certain percentage of educational/Inservice programs in your facility?

- Yes

17. If yes, what percentage?

18. Are there staff members available in the facility with sufficient knowledge to educate others (residents, families, and employees) about HIVIAIDS?

$$
\begin{aligned}
& \text { Yes } \\
& \text { - No }
\end{aligned}
$$

\section{Concerns}

19. What are some of the nursing facilities concerns about placement of HIVIAIDS infected individuals? (check all that apply)

Cost of care

Staff turnover rate

_ Fear of losing potential residents
_ Fear of infection from AIDS patients

Fear of community disapproval

Other:

\section{Resources}

20. Check all of the following agencies that are available within the community to assist the facility in caring for HIVIAIDS infected individuals?

_ County Health Department

_ Counseling services
_Hospice

Bereavement counseling Other agencies:

21. Is nursing facility currently able to meet the medical needs of HIVIAIDS infected individuals ?

Yes
- No
— Don't know

22. Is nursing facility currently able to meet the custodial care needs of HIVIAIDS infected individuals ?

Yes
- No
— Don't know




\section{Experience}

23. Is nursing facility currently caring for HIVIAIDS infected individual(s)?

$$
\begin{aligned}
& \text { Yes } \\
& \text { - No }
\end{aligned}
$$

24. If yes, how many?

$$
\begin{aligned}
& \text { 1-2 } \\
& -3-4 \\
& -5-6 \\
& -7 \text { or more }
\end{aligned}
$$

25. If no, has the nursing facility been asked to accept an HIVIAIDS patient and could not?

$$
\text { - Yes }
$$

26. If yes, please explain:

27. Would the nursing facility consider admission of an HIVIAIDS infected individual(s)?

$$
\begin{aligned}
& \text { Yes } \\
& \text { - Maybe, depending on situation } \\
& \text { - No }
\end{aligned}
$$

28. Have any incidents occurred within the facility relating to the subject of HIVIAIDS?

$$
\begin{aligned}
& \text { Yes } \\
& \text { - No } \\
& \text { — Don't know }
\end{aligned}
$$

29. If yes, please explain:

30. Have any of the staff ever quit or threatened to quit if they had to care for an HIVIAIDS patient?

Yes, quit

Yes, threatened to quit

No

Is there anything you'd like to tell us about the issue of HIVIAIDS in nursing homes? 


\section{APPENDIX E: IRB Approval Notice}

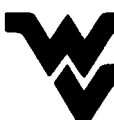

The Institutional Review Board for the Protection of Human Subjects

\section{West Virginia University}

DATE: October 13, 1999

NOTICE OF APPROVAL FOR PROTOCOL H.S. \#14584

This research will be monitored for re-approval annually. This protocol was first approved on October 13, 1999.

TO: Valerie Bell and Irene Tessaro

Project Title: A Look at HIV/AIDS in WV Nursing Homes

SPONSORING AGENCY: N/A

The Institutional Review Board for the Protection of Human Research Subjects (IRB) has approved the project described above. Approval was based on the descriptive material and procedures you submitted for review. Should any changes in your protocol/consent form be necessary, prior approval must be obtained from the IRB.

According to the Code of Federal Regulations, Section 312.32, investigators are required to notify the FDA and the study sponsor of any adverse experience associated with the use of an investigational drug that is serious and unexpected. A serious adverse experience is considered any event that is fatal or life-threatening, is permanently disabling, requires inpatient hospitalization, or is a congenital anomaly, cancer, or overdose. An unexpected adverse experience is an event that is not identified in nature, severity, or frequency in the current investigator brochure. Any experience reportable to FDA and the sponsor must also be reported immediately to the IRB.

A consent form* is $\mathrm{X}$ is not required of each subject.

An assent form_ is $\mathrm{X}$ is not required of each subject.

A recruitment ad has has not $\mathrm{X}$ been approved.

NOTE: Consent form waiver has been approved. 
APPENDIX E: IRB Approval Notice, page 2

Page 2-

Bell

HS \#14584

October 13,1999

* Only copies of the consent and/or assent form with the IRB's approval stamp may be used with human subject research. It is the responsibility of the investigator to submit a revised consent form for the IRB's approval should funding be obtained. This stamped consent form must then be used for subjects enrolled. A copy of each subject's signed Consent/Assent Form must be retained by the investigator and accessible to federal regulatory authorities for at least three years after the study is completed.

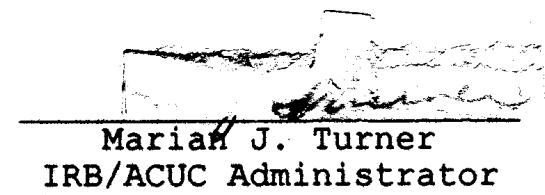

MJT/baw 